\title{
Improving Yield, Quality and Storability of "Samani" Date Palm Fruits by Some Pre- and Post-Harvest Treatments
}

\author{
Ezz, Thanaa M. ${ }^{1}$, M. A. Aly. ${ }^{1}$ Ekbal Z. A. Ahmed ${ }^{2}$, and M. H. A. \\ Khalaf $^{3}$ \\ 1.Professor of Pomology, Faculty of Agriculture (Saba Basha) Alexandria University. \\ 2.Head Researcher, Horticulture Research Institute, Agricultural Research Centre, Giza, Egypt. \\ 3.Assistant Researcher, Horticulture Research Institute, Agricultural Research Centre, Giza, Egypt. \\ DOI: 10.21608/jalexu.2021.108332.1023
}

\begin{abstract}
Article Information
Received:November $28^{\text {Th }}$ 2021

Revised: December $12^{\text {nd }}$ 2021

Accepted:December $23^{\text {rd }}$ 2021

Published: December $30^{\text {th }}$ 2021
\end{abstract}

ABSTRACT: The aim of this investigation is to study some pre- and postharvesting treatments affecting yield, quality and storability of "Samani" datepalm fruits. The field experiments were carried out in Al Bousily Research Station in El Behira governorate, Egypt in seasons of 2019 1nd 2020. The effect of growth regulators such as: Naphthalene Acetic Acid "NAA" (80 and 90 mg/l at hababak stage and 50 and $60 \mathrm{mg} / \mathrm{l}$ at the beginning of fruit color break). and N-2-chloro-4-pyridyl-N-phenylurea "CPPU" (5 and $10 \mathrm{mg} / \mathrm{l}$ at hababak stage and 10 and $15 \mathrm{mg} / \mathrm{l}$ at the beginning of fruit color break) on yield and physical and chemical characteristics were investigated In addition, the effect of dipping the fruits in oils such as: lemongrass $(0.4$ and $0.8 \%$ ) and peppermint (4 and 8 $\%$ ) and cold-storage durations of zero, 15, 30 and 45 day on physical and chemical characteristics (weight loss, total soluble solids content (TSS), acidity, TSS/acidity ratio, tannins, chlorophyll and carotene) were evaluated during storage period. The best growth regulator which gave the suitable yield and physical and chemical characteristics of "Samani" dates was NAA "90 mg/l at hababak stage and $60 \mathrm{mg} / \mathrm{l}$ at the beginning of fruit color break". It gave "Samani" date-fruits yield of 283.93 - $308.77 \mathrm{~kg} /$ tree, bunch weight of 20.74 $21.93 \mathrm{~kg} / \mathrm{bunch}$, fruit weight of $36.43-40.54 \mathrm{~g} /$ fruit, fruit volume of $32.16-$ $33.76 \mathrm{~cm}^{3}$, TSS of $24.6227 .8 \%$, Acidity of $0.23-0.25 \%$, TSS/Acidity of $98.16-118.77 \%$, vitamin C of $3.81-4.19 \mathrm{mg} / 100 \mathrm{fw}$, total sugar of $21.74-$ $23.65 \%$, tannins of $0.41-0.43 \%$, chlorophyll of $10.14-11.17 \mathrm{mg} / 100 \mathrm{~g}$ and carotene of $4.08-4.45 \mathrm{mg} / 100 \mathrm{~g}$. The best "Samani" date-palm fruit-quality using the optimum growth regulator of NAA " $90 \mathrm{mg} / \mathrm{l}$ at hababak stage and 60 $\mathrm{mg} / \mathrm{l}$ at the beginning of fruit color break" and fruit dipping on oils of peppermint $8 \%$ at cold storage conditions of " $0 \pm 1{ }^{\circ} \mathrm{C}$ with R. H. $85-90 \%$ " for best duration of 45 days were: weight loss of $5.46-5.82 \%$, TSS of $27.4-29.5 \%$, acidity of $0.15 \%$, TSS/Acidity of $182-197 \%$, vitamin C of $2.79-2.82 \%$, total sugar of $24.6-25.1 \%$, tannins of $0.15-0.16 \%$, chlorophyll of $5.1-6.7 \mathrm{mg} / 100$ $\mathrm{g}$ and carotene of $5.7-6.2 \mathrm{mg} / 100 \mathrm{~g}$ in both seasons of 2019 and 2020 .

Keywords: Growth-regulators - fruits storability - lemongrass - peppermint - Samani fruits quality.

\section{INTRODUCTION}

Date palms are considered one of the oldest trees known to ancient people as a source of food. Egypt is considered one of the greatest countries in palmdate production in the world. The total production of date fruits in Egypt is about 1.6 million tons/year (FAO, 2021). Egypt has many cultivars such as "Zaghloul", "Samani", "Halaway" and "Hayany" which are grown in different regions. They are the earliest ripening varieties of soft-date grown in Egypt. "Zaghloul" date is the most important commercial cultivar in Egypt and highly demanded in the Arab markets (Kassem et al., 2011). The process of storing dates is necessary to market demands, to increase the marketing period longer than normal season and to obtain a high profit (Omaima et al., 2012) and the optimum temperature to store the fruits of dates is $0-4 \mathrm{oC}$ and relative humidity of $85-90 \%$ (AlRedhaiman, 2005) to be stored for a month depending on the cultivar.

Growth regulators play an important role in improving quality and productivity of date palms (El-Kosary, 2009) and other fruit species (Agusti et al., 2003 and Davis, 2004) probably by increasing cell division and elongation. The application of NAA during Kimri stage cause an increase in fruit size of Zahdi and Sayer cv. (Mohammed and Shabana, 1980). GA application on Barhee ee at 50,100 and 150 ppm at 15 - 16 weeks following pollination increased fruit weight and fruit length and delayed fruit ripening (Awad and Al-Qurashi, 2012). Also, $\mathrm{GA}_{3}$ spray on Samani and Zaghloul dates at 4 weeks after pollination increased bunch weight, weights of fruit and seed (El-Kosary, 2009). Ethrel

Journal Article (C) 2021 by (JAAR) is licensed under CC BY-NC 4.0 C) 
application at hababouk and at the end of Kimri stage increased fruit weight, length, and diameter and advanced fruit ripening date of Sokary ${ }^{\text {ee }}$ dates (Kassem et al., 2012). Cold storage delayed fruit ripening and extend the shelf life of Barhee ee dates compared with store at ambient condition (AlObeed, 2010). Pre-harvest spray of gibberellic acid, naphthalene acetic acid, benzyl adenine and salicylic acid each at 50 or $100 \mathrm{ppm}$ reduced rutab percent, weight loss and delayed fruit maturation and ripening of Barhee ${ }^{e e}$ dates during cold storage (Mohammed et al., 2014). Also, Khalil (2015) found that NAA had higher bunch weight followed by $\mathrm{GA}_{3}$ and ethrel.

The development and use of alternative postharvest control options involving natural plant extracts have become important, since it is perceived as being environmentally safer and more acceptable to the general public (Janisiewicz and Korsten, 2002). Recently, researchers have shown an interest in the application of non-toxic alternatives such as, essential oil including jasmine oil which have been shown to possess antibacterial, antifungal, antiviral, insecticidal and antioxidant properties (Zaghloul et al., 2011; Sabry et al., 2011 and Gameel, 2011). Green tea extract is a powerful antioxidant, because of the high levels of polyphenols and contains different tannins, vitamins and minerals (Faissal et al., 2014). Green tea catechins and theirpolymeric oxidation products are potent inhibitors of several virulent bacterial toxins and antiviral activities of green tea catechins are observed against several pathogenic viruses (Friedman, 2007). Green tea polyphenols have shown their osteo-protective effects by decreasing oxidative stress, increasing the activity of antioxidant enzymes (Shen et al., 2011). In same trend, Zaki et al. (2017) concluded that the green tea at $2 \%$ extract and /or jasmine oil (200 ppm) treatments as solely or in combination as natural and safe material were the most effective treatments in maintaining the overall quality attributes of date palm (Phoenix dactylifera L.) fruits cv. Zaghloul during cold storage at $\left(0^{\circ} \mathrm{C}\right.$ with $85-90 \% \mathrm{RH})$ for 45 days, whereas after 60 days of cold storage none of the used treatments was clearly effective.

Cold storage delayed fruit ripening and extend the shelf life of „Barhee ${ }^{\text {ee }}$ dates compared with store at ambient condition (Al-Obeed, 2010). On the otherwise, Shamim et al. (2013) studied the effect of hot water with temperatures of 40,50 and $60{ }^{\circ} \mathrm{C}$ on fruit quality during storing ripened dates at $30 \pm$ $50{ }^{\circ} \mathrm{C}$ for 3 months.. It concluded that optimum hot-water temperature was $50{ }^{\circ} \mathrm{C}$ which gave firmness values of 2.3 and $1.8 \mathrm{~N} / \mathrm{cm} 2$ and TSS values of 62.98 and 54.39 for "Hilawi" and "Khud Ravi" date-palm cultivars respectively. In addition, Zaki et al. (2017) studied the effect of cold-storage period on "Zaghloul" date-palm fruits quality and found that loss weight-loss values were $0,15.89$, 17.04, 23.87 and $28.08 \%$, decay values were $0,14.25,20.14,21.79$ and $37.37 \%$, firmness values of 17.5, 17.0, 16.73, 14.8 and $12.33 \mathrm{lb} /$ inch $^{2}$, TSS values of $10.3,10.8,11.07,11.43$ and $10.53 \%$, acidity values of $0.37,0.37,0.43,0.33$ and 1.27 and tannins values of $3.33,2.2,1.23,1.47$ and 1.53 $\mathrm{mg} / \mathrm{g}$ for cold-durations of $0,15,30,45$ days respectively at season of 2015 In the same line, ElDengawy et al. (2018) studied the effect of coldstorage period on "Hyany" date-palm fruits quality and found that loss weight-loss values were 1.38 , $1.81,3.08$ and $1.40 \%$, decay values were $0,0,0$ and $56.7 \%$, firmness values of $16.4,16.3,13.6$ and $10.4 \mathrm{lb} / \mathrm{inch}^{2}$ and TSS values of $30.1,37.8,38.5$ and $40.0 \%$ and for cold-durations of $0,15,30,45$ days respectively. Also, Yehia and Zaki (2020) studied the effect of a mechanical pollination on quality of "Zaghloul" Date-palm fruits during cold storage. They concluded that the best "Zaghloul" date-palm fruit-quality using the tested pollinationmachine at best postharvest treatments conditions at cold storage conditions of $0 \pm 1^{\circ} \mathrm{C}$ with R. H. 85 - $90 \%$ cold-storage duration of 45 days were: weight loss of 4.7-5.2\%, decay of $20.5-20.6 \%$, fruit firmness of $14.1-14.4 \mathrm{mg} / \mathrm{cm}$, TSS of $12.4-$ $12.7 \%$, acidity of $0.24-0.37 \%$, TSS/Acidity ratio of $52.92-33.51$ and tannins of $1.44-1.51 \mathrm{mg} / \mathrm{g}$ for seasons of 2018 and 2019. Therefore, the objectives of present investigation are:

1- $\quad$ To study the effect of Naphthalene Acetic Acid "NAA" and N-2-chloro-4-pyridyl-Nphenylurea "CPPU" growth regulators on number of bunches per tree, bunch weight, fruit mass and some chemical properties of fruits for "Samani" date-palm.

2- $\quad$ To study the effect of dipping the fruits in natural safe alternatives postharvest treatments such as lemongrass and peppermint oils for improving the storability and quality of date palm fruits during cold storage, as well as marketing period of the "Samani" date-palm variety.

\section{MATERIALS AND METHODS}

\section{Experimental soil and palm conditions:}

The field experiments were carried out in $\mathrm{Al}$ Bousily Research Station in El Behira governorate, Egypt to study the effect of some pre-harvest spraying treatments on yield, fruit quality and extending storage life of Samani date palm fruits in 2019 and 2020 seasons. The conditions of the selected 15 tested trees are as follows: (a) soil type: clay, (b) palm tree variety: "Samani", (c) trees spacing: $6 \mathrm{~m}$, (d) rows spacing: $6 \mathrm{~m}$, (e) palm tree height: about $8 \mathrm{~m}$, (f) Number of bunches per tree: 10 - 14 bunch/tree.

Spraying with tested growth-regulators was carried out for 12 trees from each treatment as follows: the first application at hababak stage in June and the 
second application in the beginning of fruit color break in September.

Experiments setup:

At pre-harvesting.

This study was conducted to investigate the effects of Naphthalene Acetic Acid (NAA) and N-2chloro-4-pyridyl-N-phenylurea (CPPU) on the growth and quality development of palm tree fruits. This date palm trees were sprayed with this following treatment. The pre-harvest growth regulator treatments using 15 trees ( 5 treatments $\mathrm{x}$ 3 replicates) were designed as completely randomized design as follows:

T1: Control "Water Only".

T2: NAA (80 mg/l at hababak stage and $50 \mathrm{mg} / \mathrm{l}$ at the beginning of fruit color break).

T3: NAA $(90 \mathrm{mg} / \mathrm{l}$ at hababak stage and $60 \mathrm{mg} / \mathrm{l}$ at the beginning of fruit color break).

T4: CPPU ( $5 \mathrm{mg} / \mathrm{l}$ at hababak stage and $10 \mathrm{mg} / \mathrm{l}$ at the beginning of fruit color break).

T5: CPPU (10 mg/l at hababak stage and $15 \mathrm{mg} / \mathrm{l}$ at the beginning of fruit color break).

\section{At post harvesting.}

The present study was conducted to investigate the effects of dipping the fruits storability in oils such as: lemongrass $(0.4$ and $0.8 \%)$ and peppermint (4 and $8 \%$ ) on quality of palm tree fruits. The post harvesting treatments interacted with the previous five pre-harvesting treatments using 20 carton boxes were designed as two-factorial design for post harvesting treatments with 3 replicates as follows:

T6: T2 without dipping the fruits in essential oils.

T7: T3 without dipping the fruits in essential oils

T8: T4 without dipping the fruits in essential oils

T9: T5 without dipping the fruits in essential oils

T10: $\mathrm{T} 2+$ dipping the fruits in lemongrass oil at $0.4 \%$.

$\mathrm{T} 11: \mathrm{T} 2+$ dipping the fruits in lemongrass oil at $0.8 \%$.

$\mathrm{T} 12$ : $\mathrm{T} 2+$ dipping the fruits in peppermint oil at $4 \%$.

T13: $\mathrm{T} 2+$ dipping the fruits in peppermint oil at $8 \%$.

$\mathrm{T} 14: \mathrm{T} 3+$ dipping the fruits in lemongrass oil at $0.4 \%$.

$\mathrm{T} 15: \mathrm{T} 3+$ dipping the fruits in lemongrass oil at $0.8 \%$.

T16: $\mathrm{T} 3+$ dipping the fruits in peppermint oil at $4 \%$.

T17: $\mathrm{T} 3$ + dipping the fruits in peppermint oil at $8 \%$.

T18: T4 + dipping the fruits in lemongrass oil at $0.4 \%$.

T19: $\mathrm{T} 4+$ dipping the fruits in lemongrass oil at $0.8 \%$.

T20: $\mathrm{T} 4+$ dipping the fruits in peppermint oil at $4 \%$.
T21: $\mathrm{T} 4+$ dipping the fruits in peppermint oil at $8 \%$.

T22: $\mathrm{T} 5$ + dipping the fruits in lemongrass oil at $0.4 \%$.

$\mathrm{T} 23$ : $\mathrm{T} 5$ + dipping the fruits in lemongrass oil at $0.8 \%$.

T24: $\mathrm{T} 5$ + dipping the fruits in peppermint oil at $4 \%$.

$\mathrm{T} 25: \mathrm{T} 5+$ dipping the fruits in peppermint oil at $8 \%$.

Cold-storage conditions: Date palm fruits cv. "Samani" were harvested at the end of September during two successive seasons of 2019 and 2020. Fruits were harvested at repining stage. Harvested fruits were uniform in size, appearance, free from visible physical and pathological defects. Harvested fruits were transferred to the laboratory for further treatments at the same day of harvest. Fruits sampled randomly from each tree were thoroughly washed with tap water only and left to air dry completely. The fruits then packed in carton boxes with size about $5 \mathrm{~kg}$ and stored at $0 \pm 1{ }^{\circ} \mathrm{C}$ with $85-90 \%$ relative humidity. Cold-storage durations of $0,15,30$ and 45 were tested. Ten fruits from each carton box were used for weight loss determination every 15 days during the storage periods. Ten fruits were also, taken from the carton box every 15 days for the determination of physical and chemical fruit properties.

The studied characters:

Pre-harvesting measurements:

Physical properties: "Samani" fruit-yield (kg), bunch weight $(\mathrm{kg})$ and fruit weight $(\mathrm{g})$ were measured using tested growth regulators.

Chemical properties: "TSS", Acidity, "TSS/acidity", total sugar, vitamin C, tannins, Chlorophyll and carotene for "Samani" date-fruits were determined.

\section{Cold-storage measurements:}

1- Weight loss (\%): Fruits were weighed before and after an interval of 15 days for a total coldstorage period of 45 days. The fruit weight loss percent was calculated by the following equation (Vicente et al., 2003):

Fruit weight loss, $\%=\left(\mathrm{W}_{1}-\mathrm{W}_{2}\right) \times 100 / \mathrm{W}_{1}$

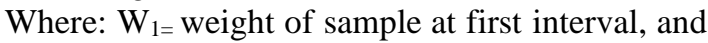
$\mathrm{W}_{1=}$ weight of sample at second interval.

2- Total soluble solids (TSS) percent: Total soluble solids percent (TSS, \%) was measured for tested date-palm fruit juice using digital hand refractometer (Model Palette, PR-32, Atago)..

3- Acidity percent: Total acidity-percent was expressed as malic acid and determined by titrating $5 \mathrm{ml}$ juice with $0.1 \mathrm{~N}$ sodium hydroxide using phenolphthalein as an indicator.

4- Total soluble solids / Total acidity ratio: was calculated by dividing TSS (\%) by total acidity (\%), as the methods described by A.O.A.C., (2000). 
5- Vitamin C: The ascorbic acid content of the juice was determined by titration with 2, 6 dichloro phenol-indo-phenol (A.O.A.C., 2000) and calculated as (mg/100 ml juice).

6- Total sugar: Total sugar percentage were determined according to the method of Malik and Singh (1980).

7- Total tannins content: Total tannins were estimated as $\mathrm{mg}$ per $\mathrm{g}$ fresh weight due to the method described by A.O.A.C., (2000).

8- Carotene and total chlorophyll contents: Carotenoids and total chlorophyll contents (mg/100 g peel fresh weight) were achieved by the method of Moran and Porath (1980), as $80 \%$ acetone extract was colorimetrically assayed at 440 $\mathrm{nm}$ for caroteneand $650 \mathrm{~nm}$ for total chlorophyll using a Spectrophotometer.

Statistical analysis: Data of the present study were subjected to the analysis of variance test (ANOVA) as completely randomized design for preharvesting treatments and two factorial design for post harvesting treatments. ANOVA and least significant differences (LSD) at the $5 \%$ level of probability were calculated using a computer program "SAS" (SAS, 2000) version 8.02.

\section{RESULTS AND DISCUSSION}

A. Pre-harvesting results:

1. Effect of growth-regulators "NAA" and "CPPU") on bunch weight, fruit weight, length, diameter and volume.

Tables (1) and (2) show the effect of growthregulators "NAA" and "CPPU" on "Samani" datefruit yield, bunch weight, fruit weight, length, diameter and volume for 2019 and 2020 seasons. The "Samani" dare-palm fruit yield, bunch weight, fruit weight, length, diameter and volume significantly increased by increasing "NAA" and "CPPU" concentrations compared with control treatment (without growth regulator). It was found that the tested second season of 2020 Samani values higher than the first season of 2019 for all measurements.

Results revealed that by increasing "NAA" from 50 to $60 \mathrm{mg} / \mathrm{l}$ "Samani" yield increased from 274.03 to 283.93 and from 300.44 to 308.77 $\mathrm{kg} /$ tree, bunch weight increased from 20.12 to 20.74 and from 21.93 to $21.93 \mathrm{~kg}$, fruit weight increased from 36.48 to 40.54 and from 33.59 to $36.43 \mathrm{~g}$, fruit length increased from 4.56 to 5.06 and from 4.34 to $4.86 \mathrm{~cm}$, fruit diameter increased from 3.24 and 3.41 and from 3.12 to $3.32 \mathrm{~cm}$ and fruit volume increased from 31.63 to 33.76 and from 30.14 to $32.16 \mathrm{~cm}^{3}$ in the two studied seasons of 2019 and 2020 respectively.

The results showed that the "Samani" date-palm trees treated with "NAA" gave the maximum of average yield of $291.79 \mathrm{~kg} /$ tree, bunch weight of $21.8 \mathrm{~kg} / \mathrm{bunch}$, fruit weight of $36.76 \mathrm{~g} /$ fruit and volume of and $31.93 \mathrm{~cm}^{3}$. Meanwhile, "CPPU" treatment gave the average yield of $269.47 \mathrm{~kg} / \mathrm{tree}$, bunch weight of $20.39 \mathrm{~kg} / \mathrm{bunch}$, fruit weight of $32.41 \mathrm{~g} /$ fruit and volume of and $28.93 \mathrm{~cm}^{3}$ in both seasons.

The increase in yield obtained by the mentioned substances might be due to the fact that they also increased fruit and bunch weight in this study. A similar increase in the yield by different GA3 and CPPU sprays was recorded by (Rizk-Alla and Meshrake, 2006). The role of exogenous applied polyamines in increasing tree yield was previously stated by (Melouk, 2007). The pre-harvest application of all growth regulators had positive influences in increasing fruit weight, diameter, length and volume of "Samani" date. Also, the growth regulators retarded fruit green color break of "Samani" dates. This increment in fruit physical characteristics was also reported by numerous

Table 1: Effect of growth-regulators "NAA" and "CPPU" on "Samani" date-fruit yield, bunch weight and fruit weight in 2019 and 2020 seasons.

\begin{tabular}{lcccccc}
\hline \multirow{2}{*}{$\begin{array}{l}\text { Growth regulators } \\
(\mathbf{G R})\end{array}$} & \multicolumn{2}{c}{ Yield (kg/tree) } & \multicolumn{2}{c}{ Bunch Weight (kg) } & \multicolumn{2}{c}{ Fruit Weight $(\mathbf{g})$} \\
\cline { 2 - 7 } Control & $\mathbf{2 0 1 9}$ & $\mathbf{2 0 2 0}$ & $\mathbf{2 0 1 9}$ & $\mathbf{2 0 2 0}$ & $\mathbf{2 0 1 9}$ & $\mathbf{2 0 2 0}$ \\
\hline NAA c1 & 204.57 & 216.48 & 17.47 & 19.04 & 26.04 & 23.32 \\
\hline NAA c2 & 274.03 & 300.44 & 20.12 & 21.93 & 36.48 & 33.59 \\
\hline CPPU c1 & 283.93 & 308.77 & 20.74 & 21.93 & 40.54 & 36.43 \\
\hline CPPU c2 & 257.28 & 271.54 & 19.64 & 20.92 & 32.26 & 29.23 \\
\hline Mean & 263.80 & 285.27 & 19.79 & 21.21 & 36.17 & 31.98 \\
\hline LSD 0.05 & 269.76 & 291.51 & 20.07 & 21.50 & 36.36 & 32.81 \\
\hline
\end{tabular}

Control: Control "Water".

NAA c1: $(80 \mathrm{mg} / \mathrm{l}$ at hababak stage and $50 \mathrm{mg} / \mathrm{l}$ at the beginning of fruit color break).

NAA c2: (90 mg/l at hababak stage and $60 \mathrm{mg} / \mathrm{l}$ at the beginning of fruit color break).

CPPU c1: ( $5 \mathrm{mg} / \mathrm{l}$ at hababak stage and $10 \mathrm{mg} / \mathrm{l}$ at the beginning of fruit color break).

CPPU c2: (10 mg/l at hababak stage and $15 \mathrm{mg} / \mathrm{l}$ at the beginning of fruit color break). 
(JAAR) Volume: 26 (4)

Table 2: Effect of growth-regulators "NAA" and "CPPU" on "Samani" date-fruit length, diameter and volume in 2019 and 2020 seasons.

\begin{tabular}{ccccccc}
\hline $\begin{array}{c}\text { Growth } \\
\text { regulators } \\
(\text { GR) }\end{array}$ & $\mathbf{2 0 1 9}$ & $\mathbf{2 0 2 0}$ & $\mathbf{2 0 1 9}$ & $\mathbf{2 0 2 0}$ & $\mathbf{2 0 1 9}$ & $\mathbf{2 0 2 0}$ \\
\cline { 2 - 6 } & 3.11 & 3.00 & 2.56 & 2.45 & 24.01 & 22.86 \\
\hline Control & 4.56 & 4.34 & 3.24 & 3.12 & 31.65 & 30.14 \\
\hline NAA c1 & 5.06 & 4.86 & 3.41 & 3.32 & 33.76 & 32.16 \\
\hline NAA c2 & 3.65 & 3.47 & 2.91 & 2.79 & 28.48 & 27.36 \\
\hline CPPU c1 & 4.05 & 3.86 & 3.07 & 2.93 & 30.38 & 29.49 \\
\hline CPPU c2 & 4.33 & 4.13 & 3.16 & 3.04 & 31.07 & 29.79 \\
\hline Mean & 0.038 & 0.10 & 0.009 & 0.061 & 1.02 & 1.18 \\
\hline LSD at $\mathbf{0 . 0 5}$ & & & & & & \\
\hline
\end{tabular}

Control: Control "Water".

NAA c1: (80 mg/l at hababak stage and $50 \mathrm{mg} / \mathrm{l}$ at the beginning of fruit color break).

NAA c2: (90 mg/l at hababak stage and $60 \mathrm{mg} / \mathrm{l}$ at the beginning of fruit color break).

CPPU c1: (5 mg/l at hababak stage and $10 \mathrm{mg} / \mathrm{l}$ at the beginning of fruit color break).

CPPU c2: (10 mg/l at hababak stage and $15 \mathrm{mg} / \mathrm{l}$ at the beginning of fruit color break).

researchers working on different fruit species (Aljuburi et al., 2000; Stern et al., 2006; Aboutalebi and Beharoznam, 2006; Kassem et al., 2011). The improvement in fruit physical properties as a result of the different sprayed growth regulators might be due to their influence in enlarging cell size and enhancing the strength of carbohydrate sink, thus increasing fruit size and weight. In this way, Kuiper (1993) suggested that sink strength is established and regulated by plant growth regulators which stimulate transport of nutrients through the phloem, modify the strength of the sink by stimulating fruit growth and increase the ability for sugar unloading from the phloem. They may also act on metabolism and compartmentalization of sugar and its metabolites (Brenner and Cheikh, 1995). CPPU has been reported to stimulate both cell division and cell elongation resulting in fruit size increase when applied shortly after fruit set (Dokoozlain, 2000). The increase in yield obtained by the mentioned substances might be due to the fact that they also increased fruit and bunch weight in this present study. A similar increase in the yield by different GA3 and CPPU sprays was recorded by (RizkAlla and Meshrake, 2006). CPPU spray was found to delay chlorophyll breakdown and fruit aging (Yuan et al., 2004). CPPU treatments also noticeably delayed maturity (Zai-xin and Yongling, 2005).
2. Effect of growth-regulators "NAA" and "CPPU") on "Samani" palm-date fruit chemical properties.

Tables (3) and (4) show the effect of growth-regulators "NAA" and "CPPU" on "TSS", Acid, "TSS/Acid", vitamin C percent, total sugar, tenines percent, chlorophyll and carotine of Samani" date-fruits for 2019 and 2020 seasons.

\subsection{Total soluble solids (TSS).}

Table (3) shows that total soluble solids (TSS) of Samani" date-fruits significantly increased by increasing concentration of "NAA" and "CPPU" growth regulators compared with control treatment (without growth regulators) in the two seasons..

It was found that total soluble solids (TSS) of Samani" date-fruits increased by all sprayed growth regulators NAA, CPPU as compared with the control treatment in both seasons. There was no significant difference between NAA and CPPU. The maximum total soluble solids (TSS) values of 28.15 and $25.92 \%$ were obtained using CPPU c2: (10 $\mathrm{mg} / \mathrm{l}$ at hababak stage and $15 \mathrm{mg} / \mathrm{l}$ at the beginning of fruit color break) in the first and second seasons respectively. Meanwhile, the minimum fruit TSS values of 22.48 and $20.45 \%$ were obtained using control treatment (without growth regulators) at first and second seasons of 2019 and 2020, respectively. 
Table 3: Effect of growth-regulators "NAA" and "CPPU" on "TSS", Acidity, "TSS/Acidity" and vitamin C percent of Samani" date-fruits in 2019 and 2020 seasons.

\begin{tabular}{|c|c|c|c|c|c|c|c|c|}
\hline \multirow{2}{*}{$\begin{array}{l}\text { Growth } \\
\text { regulators } \\
\text { (GR) }\end{array}$} & \multicolumn{2}{|c|}{ TSS (\%) } & \multicolumn{2}{|c|}{ Acidity (\%) } & \multicolumn{2}{|c|}{$\begin{array}{l}\text { TSS/Acidity } \\
\text { (ratio) }\end{array}$} & \multicolumn{2}{|c|}{$\begin{array}{l}\text { Vitamin } \\
(\mathrm{mg} / 100 \mathrm{fw})\end{array}$} \\
\hline & 2019 & 2020 & 2019 & 2020 & 2019 & 2020 & 2019 & 2020 \\
\hline Control & 22.48 & 20.45 & 0.28 & 0.31 & 79.70 & 65.91 & 3.17 & 2.81 \\
\hline NAA c1 & 25.33 & 23.45 & 0.24 & 0.27 & 104.24 & 87.72 & 3.86 & 3.51 \\
\hline NAA c2 & 27.08 & 24.62 & 0.23 & 0.25 & 118.77 & 98.16 & 4.19 & 3.81 \\
\hline CPPU c1 & 24.37 & 22.41 & 0.27 & 0.30 & 90.26 & 75.46 & 3.47 & 3.19 \\
\hline CPPU c2 & 28.15 & 25.92 & 0.25 & 0.27 & 114.41 & 95.79 & 3.77 & 3.47 \\
\hline Mean & 26.23 & 24.10 & 0.25 & 0.27 & 106.92 & 89.28 & 3.82 & 3.50 \\
\hline LSD at 0.05 & 0.58 & 0.63 & 0.02 & 0.02 & 6.79 & 17.65 & 0.077 & 0.08 \\
\hline
\end{tabular}

Control: Control "Water".

NAA c1: (80 mg/l at hababak stage and $50 \mathrm{mg} / \mathrm{l}$ at the beginning of fruit color break).

NAA c2: $(90 \mathrm{mg} / \mathrm{l}$ at hababak stage and $60 \mathrm{mg} / \mathrm{l}$ at the beginning of fruit color break).

CPPU c1: $(5 \mathrm{mg} / \mathrm{l}$ at hababak stage and $10 \mathrm{mg} / \mathrm{l}$ at the beginning of fruit color break).

CPPU c2: (10 mg/l at hababak stage and $15 \mathrm{mg} / \mathrm{l}$ at the beginning of fruit color break).

The increase of fruit TSS using CPUU and NAA application comparing to control treatment (without growth regulators) may be due to their influence in delayed fruit ripening process. Dhillon and Mahajan (2011) found that higher sugars and soluble solids during ripening could be due to analysis of organic compounds and starch in ethephon-treated fruits. These results confirm those of (Moustafa and Seif, 1996, Aljuburi et al., 2000), Awad and Al-Qurashi (2012) Al-Obeed (2010). The increase in TSS concentration by GA3, NAA and ethrel application is previously stated by (Aljuburi et al., 2001, Marzouk and Kassem, 2011, Awad and Al-Qurashi, 2012 and Kassem et al., 2012). Bakr et al. (2007) found that Samani and Zaghloul fruit contents of TSS, total soluble sugars, reducing and nonreducing sugars were increased and by NAA application and 100 ppm of NAA gave the highest content of TSS in Samani and Zaghloul fruit followed by $150,50 \mathrm{ppm}$ NAA and control treatment. Also, Abd El-Kader et al. (2008) found that spraying Zaghloul date-palm by NAA with different concentrations significantly increased total soluble solids. Choudhary et al. (2018) found that by increasing $\mathrm{GA}_{3}$ concentration from 50 to $200 \mathrm{ppm}$ the TSS increased from 32.04 to $39.78 \%$ for Barhee datepalm.

2.2. Acidity.

Table (3) shows that the acidity percent of Samani" datefruits significantly decreased using all sprayed growth regulators NAA, CPPU treatment as compared with the control treatment in both seasons. The Acidity decreased by increasing tested growth-regulators concentration There is no significant difference between "NAA" and "CPPU". The acidity percent for control, "NAA" and "CPPU" treatments were $0.28-0.31,0.23-0.27,0.25$ $-0.30 \%$ for all tested growth-regulator concentrations and both seasons.

The decrease of fruit acidity using CPUU and NAA application comparing to control treatment (without growth regulators) may be due to their influence in delayed fruit ripening process. Spraying CPUU and NAA in this study increased ethylene content in the fruit, accelerate fruit maturing and ripening processes. The above mentioned results are in harmony with those obtained by (Ashour et al., 2018) who included that spraying $\mathrm{GA}_{3}$ at $100 \mathrm{ppm}, 6$-benzylaminopurine (BAP) at $100 \mathrm{ppm}$, Boric acid at $250 \mathrm{ppm}$ and their mixture on
"Barhee" date-palm significantly decreased acidity. On the other hand, Ghazzawy (2013) found that the application of GA3 decreased TSS \% and delayed fruit maturation slightly. Choudhary et al. (2018) found that by increasing $\mathrm{GA}_{3}$ concentration from 50 to $200 \mathrm{ppm}$ acidity decreased from 0.33 to $0.22 \%$ for Barhee datepalm.

2.3. "TSS/Acidity".

Table (3) shows that the "TSS/Acidity" ratio significantly increased using NAA, CPPU as compared with the control treatment in both tested seasons. Also, "TSS/Acidity" ratio increased by increasing NAA, CPPU concentration. It was found the first season of 2019 gave "TSS/Acidity" values more than the second season of 2020 for all growth regulators treatments. The "TSS/Acidity" for control, "NAA" and "CPPU" treatments were $65.91-79.70,87.72-118.77$, and $75.46-114.41$ for all tested growth-regulator concentrations in both seasons.

2.4. Vitamin C.

Table (3) shows that vitamin C of "Samani" date-fruits significantly increased using NAA, CPPU as compared with the control treatment in both tested seasons. Also, vitamin $\mathrm{C}$ increased by increasing NAA and CPPU concentration. It was found that the first season of 2019 gave vitamin $\mathrm{C}$ values higher than the second season of 2020 for all growth-regulator treatments. For growthregulator treatments, the maximum values of vitamin $\mathrm{C}$ of 4.19 and $3.81 \%$ were obtained using NAA " $90 \mathrm{mg} / 1$ at "hababak" stage and $60 \mathrm{mg} / \mathrm{l}$ at the beginning of fruit color break" during 2019 and 2020 seasons, respectively. Meanwhile, the minimum values of vitamin C of 3.47 and $3.19 \%$ obtained using CPPU (5 $\mathrm{mg} / \mathrm{l}$ at "hababak" stage and $10 \mathrm{mg} / \mathrm{l}$ at the beginning of fruit color break) in 2019 and 2020 seasons, respectively. Also, for control treatment (without growth regulator), vitamin $\mathrm{C}$ values were 3.17 and $2.81 \%$ in both seasons, respectively.

\subsection{Total-sugar percent.}

Results in table (4) show that total-sugar percent of Samani" date-fruits significantly increased using NAA and CPPU as compared with the control treatment in both tested seasons. Also, total-sugar percent increased by increasing NAA and CPPU concentration in both tested seasons. It was found the tested first season of 2019 gave total-sugar percent values higher than the 
second season of 2020 for all growth-regulator treatments. The total-sugar percent for control, "NAA" and "CPPU" treatments were $15.79-17.34,19.87$ $23.65,17.91-21.29 \%$ at all tested growth-regulator concentrations in both seasons.

The results are in harmony with those reported by Bakr et al. (2007) who found that Samani and Zaghloul fruit contents of TSS, total soluble sugars, reducing and non-

Table 4: Effect of growth-regulators "NAA" and "CPPU" on total sugar, tannins percent, chlorophyll and carotene concentration of Samani" date-fruits in 2019 and 2020 seasons.

\begin{tabular}{lllllllll}
\hline $\begin{array}{l}\text { Growth } \\
\text { regulators } \\
(\mathbf{G R})\end{array}$ & \multicolumn{2}{l}{ Total sugar $(\boldsymbol{\%})$} & \multicolumn{2}{l}{ Tanines $(\boldsymbol{\%})$} & \multicolumn{2}{l}{$\begin{array}{l}\text { Chlorophyll } \\
(\mathbf{m g} / \mathbf{1 0 0 g})\end{array}$} & \multicolumn{2}{l}{$\begin{array}{l}\text { Carotine } \\
(\mathbf{m g} / \mathbf{1 0 0 g})\end{array}$} \\
\cline { 2 - 10 } & $\mathbf{2 0 1 9}$ & $\mathbf{2 0 2 0}$ & $\mathbf{2 0 1 9}$ & $\mathbf{2 0 2 0}$ & $\mathbf{2 0 1 9}$ & $\mathbf{2 0 2 0}$ & $\mathbf{2 0 1 9}$ & $\mathbf{2 0 2 0}$ \\
\hline Control & 17.34 & 15.79 & 0.62 & 0.65 & 6.94 & 7.80 & 4.80 & 4.59 \\
\hline NAA c1 & 21.90 & 19.87 & 0.45 & 0.48 & 9.50 & 10.54 & 4.19 & 3.84 \\
\hline NAA c2 & 23.65 & 21.74 & 0.41 & 0.43 & 10.14 & 11.17 & 4.45 & 4.08 \\
\hline CPPU c1 & 19.70 & 17.91 & 0.56 & 0.59 & 8.88 & 9.71 & 3.36 & 3.11 \\
\hline CPPU c2 & 21.29 & 19.42 & 0.51 & 0.53 & 9.29 & 10.22 & 3.53 & 3.25 \\
\hline Mean & 21.64 & 19.74 & 0.48 & 0.51 & 9.45 & 10.41 & 3.88 & 3.57 \\
\hline LSD at 0.05 & 0.97 & 0.81 & 0.013 & 0.023 & 0.36 & 0.37 & 0.19 & 0.37 \\
\hline
\end{tabular}

Control: Control "Water".

NAA c1: ( $80 \mathrm{mg} / \mathrm{l}$ at hababak stage and $50 \mathrm{mg} / \mathrm{l}$ at the beginning of fruit color break).

NAA c2: (90 mg/l at hababak stage and $60 \mathrm{mg} / \mathrm{l}$ at the beginning of fruit color break).

CPPU c1: (5 mg/l at hababak stage and $10 \mathrm{mg} / 1$ at the beginning of fruit color break).

CPPU c2: (10 mg/l at hababak stage and $15 \mathrm{mg} / \mathrm{l}$ at the beginning of fruit color break).

\subsection{Tannins percent.}

Results in table (4) show that tannins of "Samani" date-fruits significantly decreased using NAA and CPPU as compared with the control treatment in both tested seasons. Also, tannins decreased by increasing NAA and CPPU concentration. It was found that the second season of 2020 gave tanines values higher than the first season of 2019 for all growth-regulator treatments. For growth-regulator treatments, the maximum values of tannins of 0.56 and $0.59 \%$ were obtained using CPPU ( $5 \mathrm{mg} / \mathrm{l}$ at hababak stage and $10 \mathrm{mg} / \mathrm{l}$ at the beginning of fruit color break) in 2019 and 2020 seasons, respectively. Meanwhile, the minimum values of tannins of 0.41 and $0.43 \%$ obtained using NAA $(90 \mathrm{mg} / \mathrm{l}$ at hababak stage and $60 \mathrm{mg} / \mathrm{l}$ at the beginning of fruit color break) in 2019 and 2020 seasons, respectively. Also, for control treatment (without growth regulator), tannins values were 0.62 and $0.65 \%$ in both seasons, respectively.

In the present study, the increase in soluble tannins concentrations in fruits decreased using CPUU and NAA application might be due to their influence in delayed fruit ripening process. The results is similar to the results obtained by Abd El-Kader et al. (2008) who found that spraying Zaghloul date-palm by NAA that significant reduced tannins content was observed at 40 and 50 ppm NAA treatments than the control in both seasons.

\subsection{Chlorophyll content.}

Results in table (4) show that chlorophyll of Samani" date-fruits significantly increased using NAA and CPPU as compared with the control treatment in both tested seasons. Also, chlorophyll increased by increasing NAA and CPPU concentration in both tested seasons. It was found that the second season of 2020 gave chlorophyll values higher than the first season of 2019 for all growth-regulator treatments. The chlorophyll for control, "NAA" and "CPPU" treatments were $6.94-7.80,9.50-11.17$ and 8.88 $-10.22 \mathrm{mg} / 100 \mathrm{~g}$ for all tested growth-regulator concentrations in both seasons.

The increasing of fruit chlorophyll using CPUU and NAA application comparing to control treatment (without growth regulators) may be due to their influence in delayed fruit ripening process as mentioned before (Moustafa and Seif, 1996; Aljuburi et al., 2000) working on date palm. The results is in harmony with (Kassem et al., 2012) who studied spraying Sokary date palm growing in Riyadh area, Saudi Arabia by NAA, GA3, CPPU, Put and SA substances increased significantly chlorophyll with all treatments (except Eth) during both seasons.

\subsection{Carotene.}

Results in table (4) show that carotene of Samani" date-fruits significantly decreased using NAA and CPPU as compared with the control treatment in both tested seasons. Also, carotene increased by increasing NAA and CPPU concentration in both tested seasons. It was found that the first season of 2019 gave carotene values higher than the second season of 2020 for all growth-regulator treatments. The carotene for control, "NAA" and "CPPU" treatments were 4.59 
- 4.80, $3.84-4.45$ and $3.11-3.53 \mathrm{mg} / 100 \mathrm{~g}$ for all tested growth-regulator concentrations in both seasons as compared with the water sprayed control.

The results is in harmony with (Kassem et al., 2012) who studied spraying Sokary date palm growing in Riyadh area, Saudi Arabia by NAA, GA3, CPPU, Put and SA substances and found that the fruit carotene content decreased at rutab stage in both seasons as compared with the water sprayed control and Eth. No significant differences were obtained between NAA, CPPU, Put and SA during both seasons.

B. Cold-storage (Post harvesting) results:

Effect of Naphthalene Acetic Acid "NAA" and N-2-chloro-4-pyridyl-N-phenylurea "CPPU" growth-regulators, dipping in lemongrass and peppermint oils and cold-storage duration on fruit weight and some chemical properties of fruits for "Samani" date:

1. Effect of "NAA" and "CPPU" growthregulators, dipping fruits in oils and coldstorage duration on fruit-weight loss.

Table (5) shows the effect of growthregulators "NAA" and "CPPU" dipping in oils and cold-storage duration on fruit weight for "Samani" dates: in 2019 and 2020 seasons. The fruit-weight loss of Samani" date-fruits significantly decreased using NAA, CPPU, "NAA + lemongrass oil", "NAA + peppermint oil", "CPPU + lemongrass oil", and CPPU + peppermint oil" as compared with the control treatment at all tested concentrations, cold-storage durations and seasons. Also, fruit-weight loss decreased by increasing NAA, CPPU, lemongrass and peppermint oil concentrations at all tested coldstorage durations and seasons. The fruit-weight loss of Samani" date-fruits significantly increased by increasing cold-storage duration at all tested growth-regulators, oils and seasons.

Results revealed that the maximum fruitweight losses of 8.23 and $8.51 \%$ were obtained using "Water + CPPU c1" treatment (washing "Samani" date-fruits by water treated preharvesting with $5 \mathrm{mg} / \mathrm{l}$ at hababak stage and 10 $\mathrm{mg} / \mathrm{l}$ at the beginning of fruit color break) and cold-storage duration of 45 days in 2019 and 2020 seasons respectively.. Meanwhile, the minimum fruit losses of 2.64 and $2.96 \%$ were obtained using "NAA c2 + lemongrass $0.8 \%$ " (NAA $90 \mathrm{mg} / \mathrm{l}$ at hababak stage and $60 \mathrm{mg} / \mathrm{l}$ at the beginning of fruit color break + fruit dipping in lemon grass oil) and cold-storage duration of 15 days for 2019 and 2020 seasons respectively.

Weight loss is an important factor that limits postharvest fruit storage life (Adato and Gazit, 1974). In the present study, NAA and CPUU decreased weight loss, this is in contrast to what observed by Mohamed et al. (2014) who found that weight loss of "Barhee" dates was significantly higher at 50 and 100 ppm of GA3 and NAA compared to control. The reduction of weight loss might be due to the effect of sprayed substances on maintaining and slowing down water loss (Lester and Grusak, 2004, Mahajan and Dhatt, 2004).

2. Effect of cold-storage duration, growthregulators "NAA" and "CPPU", dipping in lemongrass and peppermint oils on some fruit chemical properties.

2.1. "TSS" percent.

Table (6) shows the effect of growthregulators "NAA" and "CPPU" dipping in oils and cold-storage duration on "TSS" percent for "Samani" date-fruits in 2019 and 2020 seasons. The TSS percent of Samani" date-fruits significantly increased using NAA, CPPU, "NAA + lemongrass oil", "NAA + peppermint oil", "CPPU + lemongrass oil", "CPPU + peppermint oil" as compared with the control treatment (Without growth regulators and without dipping in oils) at all tested concentrations, cold-storage durations and seasons.

Also, "TSS" percent increased by increasing NAA, CPPU and peppermint, and by decreasing, lemongrass oil concentrations at all tested cold-storage durations and seasons. The "TSS" percent of Samani" date-fruits significantly increased by increasing cold-storage duration at all tested growth-regulators, oils and seasons.

Data show that the average values of "TSS" were 21.2 - 23.2, 23.2 - 24.9, 24.6 - 26.4, $23.0-25.2$ and $25.1-26.9 \%$ for control treatment (without growth regulator), NAA c1 " $80 \mathrm{mg} / \mathrm{l}$ at hababak stage and $50 \mathrm{mg} / \mathrm{l}$ at the beginning of fruit color break", NAA c2"90 
Table 5: Effect of growth-regulators "NAA" and "CPPU" dipping fruits in oils and coldstorage duration on fruit weight-loss percent of "Samani" dates in 2019 and 2020 seasons.

\begin{tabular}{|c|c|c|c|c|c|c|c|c|c|c|}
\hline \multirow{4}{*}{$\begin{array}{c}\text { A- Growth regulators } \\
\text { (GR) }\end{array}$} & \multicolumn{10}{|c|}{ Weight loss, \%. } \\
\hline & \multicolumn{5}{|c|}{2019} & \multicolumn{5}{|c|}{2020} \\
\hline & \multicolumn{10}{|c|}{ B- Cold-storage duration, (day). } \\
\hline & $\mathbf{0}$ & 15 & 30 & 45 & $\begin{array}{c}\text { Mean } \\
\text { (B) }\end{array}$ & $\mathbf{0}$ & 15 & 30 & 45 & $\begin{array}{c}\text { Mean } \\
\text { (B) }\end{array}$ \\
\hline Control (Water) & 0 & 4.06 & 6.07 & 9.05 & 4.79 & 0 & 5.17 & 6.15 & 7.06 & 4.59 \\
\hline Water + NAA c1 & 0 & 3.80 & 4.75 & 6.43 & 3.76 & 0 & 4.30 & 5.66 & 7.07 & 4.28 \\
\hline Water + NAA c2 & 0 & 3.46 & 4.13 & 5.25 & 3.20 & 0 & 3.89 & 5.11 & 6.03 & 3.74 \\
\hline Water + CPPU c1 & 0 & 4.33 & 5.98 & 8.23 & 4.67 & 0 & 4.91 & 6.89 & 8.51 & 5.13 \\
\hline Water + CPPU c2 & 0 & 3.76 & 4.86 & 6.55 & 3.73 & 0 & 4.26 & 5.79 & 7.14 & 4.23 \\
\hline NAA c1 + lemongrass $0.4 \%$ & 0 & 3.04 & 3.89 & 5.10 & 3.01 & 0 & 3.44 & 4.64 & 5.61 & 3.42 \\
\hline NAA c1 + lemongrass $0.8 \%$ & 0 & 2.95 & 3.61 & 4.71 & 2.82 & 0 & 3.31 & 4.37 & 5.28 & 3.24 \\
\hline NAA c1 + peppermint $4 \%$ & 0 & 3.26 & 4.41 & 5.94 & 3.40 & 0 & 3.69 & 5.07 & 6.29 & 3.76 \\
\hline NAA c1 + peppermint $8 \%$ & 0 & 3.30 & 4.44 & 6.09 & 3.46 & 0 & 3.84 & 5.35 & 6.64 & 3.96 \\
\hline NAA c2 + lemongrass $0.4 \%$ & 0 & 2.81 & 3.33 & 4.23 & 2.60 & 0 & 3.16 & 4.12 & 4.86 & 3.04 \\
\hline NAA c2 + lemongrass $0.8 \%$ & 0 & 2.64 & 2.88 & 3.51 & 2.26 & 0 & 2.96 & 3.73 & 4.31 & 2.75 \\
\hline NAA c2 + peppermint $4 \%$ & 0 & 2.93 & 3.54 & 4.89 & 2.84 & 0 & 3.28 & 4.34 & 5.20 & 3.21 \\
\hline NAA c2 + peppermint $8 \%$ & 0 & 3.19 & 4.06 & 5.46 & 3.18 & 0 & 3.57 & 4.77 & 5.82 & 3.54 \\
\hline CPPU c1 + lemongrass $0.4 \%$ & 0 & 3.44 & 4.78 & 6.64 & 3.71 & 0 & 3.90 & 5.51 & 6.86 & 4.07 \\
\hline CPPU c1 + lemongrass $0.8 \%$ & 0 & 3.36 & 4.48 & 6.14 & 3.49 & 0 & 3.71 & 5.16 & 6.38 & 3.81 \\
\hline CPPU c1 + peppermint $4 \%$ & 0 & 3.57 & 5.10 & 7.18 & 3.96 & 0 & 4.18 & 5.94 & 7.48 & 4.40 \\
\hline CPPU c1 + peppermint $8 \%$ & 0 & 3.80 & 5.64 & 8.05 & 4.37 & 0 & 4.31 & 6.35 & 7.99 & 4.66 \\
\hline CPPU c2 + lemongrass $0.4 \%$ & 0 & 3.08 & 3.92 & 5.24 & 3.06 & 0 & 3.49 & 4.67 & 5.71 & 3.47 \\
\hline CPPU c2 + lemongrass $0.8 \%$ & 0 & 2.96 & 3.60 & 4.72 & 2.82 & 0 & 3.30 & 4.38 & 5.25 & 3.23 \\
\hline CPPU c2 + peppermint $4 \%$ & 0 & 3.25 & 4.33 & 5.89 & 3.37 & 0 & 3.67 & 5.08 & 6.24 & 3.75 \\
\hline CPPU c2 + peppermint $8 \%$ & 0 & 3.40 & 4.70 & 6.50 & 3.65 & 0 & 3.86 & 5.44 & 6.72 & 4.00 \\
\hline Mean (A) & 0 & 3.32 & 4.32 & 5.84 & & 0 & 3.75 & 5.12 & 6.27 & \\
\hline LSD at 0.05 & & $\begin{array}{l}\text { owth } \\
\text { rage }\end{array}$ & $\begin{array}{l}\text { regulat } \\
\text { eriods ( }\end{array}$ & $\begin{array}{lr}s \quad(G \\
: 0.06 \\
\end{array}$ & 0.13 & & $\begin{array}{l}\text { owth } \\
\text { rage }\end{array}$ & $\begin{array}{l}\text { regul } \\
\text { riods }\end{array}$ & $\begin{array}{l}\text { ors } \\
: 0.05 \\
\end{array}$ & :0.10 \\
\hline
\end{tabular}

NAA c1: ( $80 \mathrm{mg} / \mathrm{l}$ at hababak stage and $50 \mathrm{mg} / \mathrm{l}$ at the beginning of fruit color break).

NAA c2: (90 mg/l at hababak stage and $60 \mathrm{mg} / \mathrm{l}$ at the beginning of fruit color break).

CPPU c1: (5 mg/l at hababak stage and $10 \mathrm{mg} / \mathrm{l}$ at the beginning of fruit color break).

CPPU c2: (10 mg/l at hababak stage and $15 \mathrm{mg} / \mathrm{l}$ at the beginning of fruit color break).

Percentages beside lemongrass and peppermint are oil concentrations.

$\mathrm{mg} / \mathrm{l}$ at hababak stage and $60 \mathrm{mg} / \mathrm{l}$ at the beginning of fruit color break", CPPU c1 "5 mg/l at hababak stage and $10 \mathrm{mg} / \mathrm{l}$ at the beginning of fruit color break", CPPU c2 " $10 \mathrm{mg} / \mathrm{l}$ at hababak stage and $15 \mathrm{mg} / \mathrm{l}$ at the beginning of fruit color break" respectively at all tested coldstorage durations and seasons..

It was found that the averages of "TSS" of "Samani" date-fruits Using growth regulators, "growth regulators + lemongrass oil" and "growth regulators + peppermint oil" were $23.7-25.1,25.3-27.1$ and $25.6-27.4 \%$ respectively at all tested concentrations, cold-storage durations and seasons.

It was found that by increasing cold-storage duration from zero to 45 days the average "TSS" of "Samani fruits increased from $23.9-26.0$ to $26.0-28.2 \%$ for all tested growth-regulators, oils and seasons.

The cold-storage duration results in this investigation for TSS are in agreement with those reported by Al-Kahtani et al. (1998), and Azelmat et al. (2005). They reported that, TSS content in date increased gradually with increasing storage period. Significant increase in TSS content could be due to the degradation of insoluble compounds present in date fruit into soluble compounds such as the conversion of proto pectin into pectin. In addition, El-Rayes (2009) found that, a slight increase in TSS occurred in most treatments under investigation. This increase could be due to the conversion of some insoluble compounds into soluble compounds shown by Thompson and Abboodi (2003). Moreover, Aleid et al. (2014) studied fruit quality of two date cultivars, under cold storage at $5^{\circ} \mathrm{C}$ for 12 months, they reported that TSS is a parameter significantly correlated with the perception of sweetness, date flavor and aroma intensity. TSS of date was significantly increased under cold storage at $5^{\circ} \mathrm{C}$ for 12 months. (El-Hadidy et al., 2015) studied the effect of some postharvest treatments: 
paraffin, lemon grass oils and low density polyethylene bags (LDPE) on fruit quality attributes of Om El-Ferakh date fruits during cold storage. They found that treatments with paraffin oil and lemon grass oil recorded the highest value of fruit total soluble solids. ElSharony et al. (2015) investigated the efficiency of using some natural substances i.e. Arabic gum at $10 \%$, black cumin (Nigella sativa) oil at $1 \%$ as well as their combination besides untreated fruits as a control under colds storage on two date palm fruits cvs. Zaghloul and Samani harvested at full color stage (khalal). They was found that the averages of Zaghloul and Samani fruit TSS increased using all treatments comparing with control treatment, and by increasing cold-storage period from 15 to 60 day the TSS increased.

Table 6: Effect of growth-regulators "NAA" and "CPPU" dipping fruits n oils and coldstorage duration on total soluble solids "TSS" percent of "Samani" fruits in 2019 and 2020 seasons.

\begin{tabular}{|c|c|c|c|c|c|c|c|c|c|c|}
\hline \multirow{4}{*}{$\begin{array}{c}\text { A- Growth regulators } \\
\text { (GR) }\end{array}$} & \multicolumn{10}{|c|}{ TSSs, \%. } \\
\hline & \multicolumn{5}{|c|}{2019} & \multicolumn{5}{|c|}{2020} \\
\hline & \multicolumn{10}{|c|}{ B-Cold-storage duration, (day). } \\
\hline & $\mathbf{0}$ & 15 & 30 & 45 & $\begin{array}{c}\text { Mean } \\
\text { (B) }\end{array}$ & $\mathbf{0}$ & 15 & 30 & 45 & $\begin{array}{c}\text { Mean } \\
\text { (B) }\end{array}$ \\
\hline Control (Water) & 20.5 & 20.8 & 21.4 & 21.9 & 21.2 & 22.5 & 23.2 & 23.5 & 23.7 & 23.2 \\
\hline Water + NAA c1 & 25.3 & 25.7 & 26.5 & 27.2 & 26.2 & 23.5 & 23.8 & 24.4 & 24.9 & 24.1 \\
\hline Water + NAA c2 & 27.1 & 27.8 & 28.5 & 28.9 & 28.1 & 24.6 & 24.9 & 25.8 & 26.5 & 25.4 \\
\hline Water + CPPU c1 & 24.4 & 24.7 & 25.6 & 26.3 & 25.2 & 22.4 & 23.2 & 23.9 & 24.3 & 23.4 \\
\hline Water + CPPU c2 & 28.2 & 28.9 & 29.4 & 29.7 & 29.0 & 25.9 & 26.3 & 26.9 & 27.4 & 26.6 \\
\hline NAA c1 + lemongrass $0.4 \%$ & 25.3 & 26.0 & 26.8 & 27.6 & 26.4 & 23.5 & 24.0 & 24.6 & 25.4 & 24.4 \\
\hline NAA c1 + lemongrass $0.8 \%$ & 25.3 & 25.8 & 26.5 & 27.4 & 26.3 & 23.5 & 23.7 & 24.2 & 24.9 & 24.1 \\
\hline NAA c1 + peppermint $4 \%$ & 25.3 & 26.1 & 27.1 & 27.9 & 26.6 & 23.5 & 24.3 & 25.0 & 25.8 & 24.6 \\
\hline NAA c1 + peppermint $8 \%$ & 25.3 & 26.3 & 27.3 & 28.1 & 26.8 & 23.5 & 24.4 & 25.4 & 26.3 & 24.9 \\
\hline NAA c2 + lemongrass $0.4 \%$ & 27.1 & 27.4 & 28.1 & 29.0 & 27.9 & 24.6 & 25.4 & 26.3 & 27.0 & 25.8 \\
\hline NAA c2 + lemongrass $0.8 \%$ & 27.1 & 27.3 & 28.0 & 28.5 & 27.7 & 24.6 & 25.2 & 25.7 & 26.3 & 25.5 \\
\hline NAA c2 + peppermint $4 \%$ & 27.1 & 27.5 & 28.3 & 29.2 & 28.0 & 24.6 & 25.4 & 26.4 & 27.2 & 25.9 \\
\hline NAA c2 + peppermint $8 \%$ & 27.1 & 27.7 & 28.6 & 29.5 & 28.2 & 24.6 & 25.6 & 26.5 & 27.4 & 26.0 \\
\hline CPPU c1 + lemongrass $0.4 \%$ & 24.4 & 25.0 & 25.9 & 26.6 & 25.5 & 22.4 & 23.0 & 23.7 & 24.2 & 23.3 \\
\hline CPPU c1 + lemongrass $0.8 \%$ & 24.4 & 24.8 & 25.5 & 26.3 & 25.2 & 22.4 & 23.0 & 23.6 & 24.1 & 23.3 \\
\hline CPPU c1 + peppermint $4 \%$ & 24.4 & 25.2 & 25.9 & 26.8 & 25.6 & 22.4 & 23.1 & 23.9 & 24.5 & 23.5 \\
\hline CPPU c1 + peppermint $8 \%$ & 24.4 & 25.2 & 26.2 & 27.1 & 25.7 & 22.4 & 23.2 & 24.2 & 24.9 & 23.7 \\
\hline CPPU c2 + lemongrass $0.4 \%$ & 28.2 & 28.6 & 29.2 & 29.7 & 28.9 & 25.9 & 26.6 & 27.3 & 28.0 & 27.0 \\
\hline CPPU c2 + lemongrass $0.8 \%$ & 28.2 & 28.5 & 29.1 & 29.6 & 28.8 & 25.9 & 26.5 & 27.0 & 27.7 & 26.8 \\
\hline CPPU c2 + peppermint $4 \%$ & 28.2 & 28.7 & 29.5 & 29.9 & 29.1 & 25.9 & 26.8 & 27.7 & 28.4 & 27.2 \\
\hline CPPU c2 + peppermint $8 \%$ & 28.2 & 28.9 & 29.7 & 30.2 & 29.2 & 25.9 & 26.9 & 27.8 & 28.6 & 27.3 \\
\hline Mean (A) & 26.0 & 26.5 & 27.3 & 28.0 & & 24.0 & 24.7 & 25.4 & 26.1 & \\
\hline LSD at 0.05 & $\begin{array}{l}\text { Gro } \\
\text { Stor }\end{array}$ & $\begin{array}{l}\text { th reg } \\
\text { ge pei }\end{array}$ & $\begin{array}{l}\text { ulato } \\
\text { iods ( }\end{array}$ & $\begin{array}{l}\text { S (GR } \\
3): 0.10\end{array}$ & 0.20 & $\begin{array}{l}\text { Gro } \\
\text { Stor }\end{array}$ & $\begin{array}{l}\text { th reg } \\
\text { ge pei }\end{array}$ & $\begin{array}{l}\text { ulator } \\
\text { iods }\end{array}$ & $\begin{array}{l}\text { s (GR } \\
3): 0.1\end{array}$ & $:: 0.21$ \\
\hline
\end{tabular}

Zaki et al. (2017) investigated the effect of some postharvest natural extracts i.e., green tea at $2 \%$, fenugreek seeds at $0.5 \%$ and jasmine oil at 200 ppm on date palm fruits cv. 'Zaghlool' as solely or mixed dipping treatments under cold storage conditions $\left(0 \pm 1^{\circ} \mathrm{C}\right.$ with R. H. $\left.85-90 \%\right)$ for 60 days compared with control (water only). They found that the percentage of TSS increased by increasing storage period, Yehia and Zaki (2020) studied the effect of a mechanical pollination on quality of "Zaghloul" Date-palm fruits during cold storage. They found that by increasing cold-storage period of Zaghloul fruits from 0 to 60 days the TSS increased. 


\subsection{Acidity percent.}

Table (7) shows the effect of growthregulators "NAA" and "CPPU" dipping in oils and cold-storage duration on acidity percent of "Samani" date-fruits: for 2019 and 2020 seasons. The acidity percent of Samani" date-fruits significantly decreased using NAA, CPPU, "NAA, peppermint and lemongrass oils compared with the control treatment (Without growth regulators and without dipping in oils) for all tested concentrations, cold-storage durations and seasons. Also, acidity percent significantly decreased by increasing NAA and CPPU concentrations and increased by increasing peppermint and lemongrass oil concentrations for all tested cold-storage durations and seasons. The acidity percent of Samani" date-fruits significantly decreased by increasing cold-storage duration for all tested growth-regulators, oils and seasons.

Data showed that the average values of acidity were $0.18-0.31,0.17-0.27,0.16-0.25$,
$0.20-0.30$ and $0.18-0.27$ for NAA c1 " $80 \mathrm{mg} / 1$ at hababak stage and $50 \mathrm{mg} / \mathrm{l}$ at the beginning of fruit color break", NAA c2" $90 \mathrm{mg} / \mathrm{l}$ at hababak stage and $60 \mathrm{mg} / \mathrm{l}$ at the beginning of fruit color break", CPPU c1 " $5 \mathrm{mg} / \mathrm{l}$ at hababak stage and 10 $\mathrm{mg} / \mathrm{l}$ at the beginning of fruit color break", CPPU c2 " $10 \mathrm{mg} / \mathrm{l}$ at hababak stage and $15 \mathrm{mg} / \mathrm{l}$ at the beginning of fruit color break" respectively for all tested cold-storage durations and seasons..

It was found that the average of acidity of "Samani" date-fruits using growth regulators, "growth regulators + lemongrass oil" and "growth regulators + peppermint oil" were $0.21-0.23,0.21$ -0.24 and $0.20-0.23 \%$ respectively at all tested concentrations, cold-storage durations and seasons.

It was found that by increasing coldstorage duration from zero to 45 days the average of acidity of "Samani fruits decreased from 0.25 0.27 to $0.17-0.18 \%$ for all tested growthregulators, oils and seasons. 
Table 7: Effect of growth-regulators "NAA" and "CPPU" dipping fruits n oils and coldstorage duration on acidity percent of "Samani" fruits in 2019 and 2020 seasons.

\begin{tabular}{|c|c|c|c|c|c|c|c|c|c|c|}
\hline \multirow{4}{*}{$\begin{array}{c}\text { A- Growth regulators } \\
\text { (GR) }\end{array}$} & \multicolumn{10}{|c|}{ Acidity, \%. } \\
\hline & \multicolumn{5}{|c|}{2019} & \multicolumn{5}{|c|}{2020} \\
\hline & \multicolumn{10}{|c|}{ B- Cold-storage duration, (day). } \\
\hline & $\mathbf{0}$ & 15 & 30 & 45 & $\begin{array}{c}\text { Mean } \\
\text { (B) }\end{array}$ & $\mathbf{0}$ & 15 & 30 & 45 & $\begin{array}{c}\text { Mean } \\
(\mathbf{B})\end{array}$ \\
\hline Control (Water) & 0.28 & 0.24 & 0.21 & 0.18 & 0.23 & 0.31 & 0.28 & 0.24 & 0.21 & 0.26 \\
\hline Water + NAA c1 & 0.24 & 0.22 & 0.19 & 0.17 & 0.21 & 0.27 & 0.24 & 0.22 & 0.19 & 0.23 \\
\hline Water + NAA c2 & 0.23 & 0.21 & 0.18 & 0.16 & 0.20 & 0.25 & 0.22 & 0.20 & 0.17 & 0.21 \\
\hline Water + CPPU c1 & 0.27 & 0.25 & 0.22 & 0.20 & 0.24 & 0.30 & 0.27 & 0.25 & 0.22 & 0.26 \\
\hline Water + CPPU c2 & 0.25 & 0.23 & 0.20 & 0.18 & 0.22 & 0.27 & 0.24 & 0.22 & 0.19 & 0.23 \\
\hline NAA c1 + lemongrass $0.4 \%$ & 0.24 & 0.22 & 0.19 & 0.16 & 0.20 & 0.27 & 0.24 & 0.20 & 0.17 & 0.22 \\
\hline NAA c1 + lemongrass $0.8 \%$ & 0.24 & 0.23 & 0.20 & 0.17 & 0.21 & 0.27 & 0.25 & 0.20 & 0.17 & 0.22 \\
\hline NAA c1 + peppermint $4 \%$ & 0.24 & 0.20 & 0.17 & 0.15 & 0.19 & 0.27 & 0.22 & 0.19 & 0.14 & 0.21 \\
\hline NAA c $1+$ peppermint $8 \%$ & 0.24 & 0.22 & 0.18 & 0.15 & 0.20 & 0.27 & 0.24 & 0.20 & 0.16 & 0.22 \\
\hline NAA c $2+$ lemongrass $0.4 \%$ & 0.23 & 0.20 & 0.17 & 0.15 & 0.19 & 0.25 & 0.22 & 0.20 & 0.15 & 0.21 \\
\hline NAA c $2+$ lemongrass $0.8 \%$ & 0.23 & 0.20 & 0.18 & 0.16 & 0.19 & 0.25 & 0.23 & 0.20 & 0.16 & 0.21 \\
\hline NAA c $2+$ peppermint $4 \%$ & 0.23 & 0.19 & 0.17 & 0.14 & 0.18 & 0.25 & 0.21 & 0.18 & 0.14 & 0.20 \\
\hline NAA c $2+$ peppermint $8 \%$ & 0.23 & 0.20 & 0.17 & 0.15 & 0.19 & 0.25 & 0.21 & 0.19 & 0.15 & 0.20 \\
\hline CPPU c $1+$ lemongrass $0.4 \%$ & 0.27 & 0.23 & 0.18 & 0.18 & 0.22 & 0.3 & 0.27 & 0.24 & 0.21 & 0.26 \\
\hline CPPU c1 + lemongrass $0.8 \%$ & 0.27 & 0.23 & 0.21 & 0.19 & 0.23 & 0.3 & 0.27 & 0.24 & 0.21 & 0.26 \\
\hline CPPU c1 + peppermint $4 \%$ & 0.27 & 0.20 & 0.17 & 0.16 & 0.20 & 0.3 & 0.25 & 0.22 & 0.19 & 0.24 \\
\hline CPPU c $1+$ peppermint $8 \%$ & 0.27 & 0.21 & 0.19 & 0.17 & 0.21 & 0.3 & 0.26 & 0.24 & 0.2 & 0.25 \\
\hline CPPU c $2+$ lemongrass $0.4 \%$ & 0.25 & 0.22 & 0.20 & 0.18 & 0.21 & 0.27 & 0.24 & 0.22 & 0.19 & 0.23 \\
\hline CPPU c $2+$ lemongrass $0.8 \%$ & 0.25 & 0.22 & 0.20 & 0.19 & 0.22 & 0.27 & 0.25 & 0.22 & 0.2 & 0.24 \\
\hline CPPU c $2+$ peppermint $4 \%$ & 0.25 & 0.20 & 0.18 & 0.16 & 0.20 & 0.27 & 0.22 & 0.20 & 0.17 & 0.22 \\
\hline CPPU c $2+$ peppermint $8 \%$ & 0.25 & 0.21 & 0.19 & 0.17 & 0.21 & 0.27 & 0.24 & 0.21 & 0.19 & 0.23 \\
\hline Mean (A) & 0.25 & 0.21 & 0.19 & 0.17 & & 0.27 & 0.24 & 0.21 & 0.18 & \\
\hline LSD at 0.05 & $\begin{array}{l}\text { Grov } \\
\text { Stor: }\end{array}$ & $\begin{array}{l}\text { th reg } \\
\text { se pei }\end{array}$ & $\begin{array}{l}\text { ulato } \\
\text { iods ( }\end{array}$ & $\begin{array}{l}(\mathrm{GR} \\
): 0.0\end{array}$ & 0.01 & $\begin{array}{l}\text { Grov } \\
\text { Stor: }\end{array}$ & $\begin{array}{l}\text { th reg } \\
\text { ge per }\end{array}$ & $\begin{array}{l}\text { ulato } \\
\text { iods }\end{array}$ & $\begin{array}{l}\text { S (GR } \\
3): 0.0\end{array}$ & $\begin{array}{l}0.01 \\
3\end{array}$ \\
\hline
\end{tabular}

The results are in harmony with those of El-Hadidy et al. (2015) studied the effect of some postharvest treatments: paraffin, lemon grass oils and low density polyethylene bags (LDPE) on fruit quality attributes of Om El-Ferakh date fruits during cold storage. They found that

treatments with paraffin oil and lemon grass oil recorded the minimum value of fruit acidity. Zaki et al. (2017) investigated the effect of some postharvest natural extracts i.e., green tea at $2 \%$, fenugreek seeds at $0.5 \%$ and jasmine oil at 200 ppm on date palm fruits cv. 'Zaghlool' as solely or mixed dipping treatments under cold storage conditions $\left(0 \pm 1^{\circ} \mathrm{C}\right.$ with R. H. $\left.85-90 \%\right)$ for 60 days compared with control fruit (water only). They found that the percentage of total acidity increased by increasing storage period, Yehia and Zaki (2020) studied the effect of a mechanical pollination on quality of "Zaghloul" Date-palm fruits during cold storage. They found that by increasing cold-storage period of Zaghloul fruits from 0 to 60 days the acidity increased.

\subsection{TSS/Acidity ratio.}

Table (8) shows the effect of growthregulators "NAA" and "CPPU" dipping in oils and cold-storage duration on TSS/acidity of "Samani" date-fruits in 2019 and 2020 seasons. The TSS/acidity ratio of Samani" date-fruits significantly increased using NAA, CPPU, "NAA, peppermint and lemongrass oils compared with the control treatment (Without growth regulators and without dipping in oils) for all tested 
concentrations, cold-storage durations and seasons.

Also, TSS/acidity significantly decreased by increasing NAA, CPPU, peppermint and lemongrass oil concentrations for all tested coldstorage durations and seasons. The TSS/acidity of Samani" date-fruits significantly increased by increasing cold-storage duration for all tested growth regulators, oils and seasons.

Results showed that the average of TSS/acidity of "Samani" date-fruits Using growth regulators", growth regulators + lemongrass oil" and "growth regulators + peppermint oil" were 106 $-125,111-134$ and $118-145 \%$ respectively at all tested concentrations, cold-storage durations and seasons.

It was found that by increasing coldstorage duration from zero to 45 days the average
TSS/acidity of "Samani fruits increased from 88 105 to $149-170 \%$ for all tested growth-regulators, oils and seasons.

\subsection{Vitamin C.}

Table (9) shows the effect of growthregulators "NAA" and "CPPU" dipping in oils and cold-storage duration on vitamin C for "Samani" date-fruits in 2019 and 2020 seasons. The vitamin C of Samani" date-fruits significantly increased using NAA, CPPU, "NAA, peppermint and lemongrass oils compared with the control treatment (Without growth regulators and without dipping in oils) for all tested concentrations, coldstorage durations and seasons. Also, vitamin C significantly increased by increasing NAA, CPPU and peppermint and lemongrass oil

Table 8: Effect of growth-regulators "NAA" and "CPPU" dipping fruits n oils and coldstorage duration on TSS/acidity ratio of "Samani" fruits in 2019 and 2020 seasons.

\begin{tabular}{|c|c|c|c|c|c|c|c|c|c|c|}
\hline \multirow{4}{*}{$\begin{array}{l}\text { A- Growth regulators } \\
\text { (GR) }\end{array}$} & \multicolumn{10}{|c|}{ TSS/Acidity, \%. } \\
\hline & \multicolumn{5}{|c|}{2019} & \multicolumn{5}{|c|}{2020} \\
\hline & \multicolumn{10}{|c|}{ B- Cold-storage duration, (day). } \\
\hline & $\mathbf{0}$ & 15 & 30 & 45 & $\begin{array}{c}\text { Mean } \\
\text { (B) }\end{array}$ & $\mathbf{0}$ & 15 & 30 & 45 & $\begin{array}{c}\text { Mean } \\
(\text { B })\end{array}$ \\
\hline Control (Water) & 73 & 87 & 102 & 122 & 96 & 73 & 83 & 98 & 113 & 92 \\
\hline Water + NAA c1 & 106 & 117 & 138 & 160 & 130 & 87 & 99 & 111 & 131 & 107 \\
\hline Water + NAA c2 & 118 & 132 & 158 & 181 & 147 & 98 & 113 & 129 & 156 & 124 \\
\hline Water + CPPU c1 & 90 & 99 & 116 & 125 & 108 & 75 & 86 & 96 & 110 & 92 \\
\hline Water + CPPU c2 & 113 & 126 & 147 & 165 & 138 & 96 & 110 & 122 & 144 & 118 \\
\hline NAA c1 + lemongrass $0.4 \%$ & 106 & 118 & 141 & 173 & 134 & 87 & 100 & 123 & 149 & 115 \\
\hline NAA c1 + lemongrass 0.8 & 106 & 112 & 133 & 161 & 128 & 87 & 95 & 121 & 146 & 112 \\
\hline NAA c $1+$ peppermint $4 \%$ & 106 & 131 & 159 & 186 & 145 & 87 & 110 & 132 & 184 & 128 \\
\hline NAA $\mathrm{c} 1+$ peppermint $8 \%$ & 106 & 119 & 152 & 188 & 141 & 87 & 102 & 127 & 164 & 120 \\
\hline NAA c $2+$ lemongrass $0.4 \%$ & 118 & 137 & 165 & 193 & 153 & 98 & 115 & 132 & 180 & 131 \\
\hline NAA c2 + lemongrass 0.8 & 118 & 136 & 155 & 178 & 147 & 98 & 109 & 129 & 165 & 125 \\
\hline NAA c $2+$ peppermint $4 \%$ & 118 & 145 & 166 & 209 & 159 & 98 & 121 & 147 & 195 & 140 \\
\hline NAA c $2+$ peppermint $8 \%$ & 118 & 139 & 168 & 197 & 155 & 98 & 122 & 140 & 182 & 136 \\
\hline CPPU c1 + lemongrass $0.4 \%$ & 90 & 108 & 144 & 148 & 123 & 75 & 85 & 99 & 115 & 94 \\
\hline CPPU c1 + lemongrass 0.8 & 90 & 108 & 121 & 139 & 114 & 75 & 85 & 98 & 115 & 93 \\
\hline CPPU $\mathrm{c} 1+$ peppermint $4 \%$ & 90 & 126 & 153 & 168 & 134 & 75 & 92 & 109 & 129 & 101 \\
\hline CPPU c1 + peppermint $8 \%$ & 90 & 120 & 138 & 159 & 127 & 75 & 89 & 101 & 124 & 97 \\
\hline CPPU c $2+$ lemongrass $0.4 \%$ & 113 & 130 & 146 & 165 & 138 & 96 & 111 & 124 & 147 & 120 \\
\hline CPPU c2 + lemongrass 0.8 & 113 & 129 & 146 & 156 & 136 & 96 & 106 & 123 & 139 & 116 \\
\hline CPPU c $2+$ peppermint $4 \%$ & 113 & 144 & 164 & 187 & 152 & 96 & 122 & 138 & 167 & 131 \\
\hline CPPU c $2+$ peppermint $8 \%$ & 113 & 137 & 156 & 177 & 146 & 96 & 112 & 132 & 151 & 123 \\
\hline Mean $(\mathrm{A})$ & 105 & 124 & 146 & 168 & & 88 & 103 & 120 & 148 & \\
\hline LSD at 0.05 & $\begin{array}{l}\text { Gro } \\
\text { Stor }\end{array}$ & $\begin{array}{l}\text { th re } \\
\text { ge per }\end{array}$ & $\begin{array}{l}\text { gulato } \\
\text { ods (B }\end{array}$ & $\begin{array}{l}\quad(G \\
: 2.14 \\
\end{array}$ & 4.14 & $\begin{array}{l}\text { Gr } \\
\text { Sto }\end{array}$ & $\begin{array}{l}\text { wth } \\
\text { age p }\end{array}$ & $\begin{array}{l}\text { gulat } \\
\text { iods ( }\end{array}$ & $\begin{array}{l}\text { is }(\mathbf{G} \\
): 1.77\end{array}$ & ): 3.65 \\
\hline
\end{tabular}


concentrations for all tested cold-storage durations and seasons. The vitamin C of Samani" date fruits significantly decreased by increasing cold-storage duration for all tested growth-regulators, oils and seasons.

Results showed that the averages vitamin C of "Samani" date-fruits using growth regulators", growth regulators + lemongrass oil" and "growth regulators + peppermint oil" were $2.99-3.32,3.34-3.39$ and $3.16-3.18 \mathrm{mg} / 100 \mathrm{fw}$ respectively for all tested concentrations, coldstorage durations and seasons.

It was found that by increasing coldstorage duration from zero to 45 days the average of vitamin C of "Samani fruits decreased from 3.50 -3.82 to $2.64-2.75 \mathrm{mg} / 100 \mathrm{fw}$ for all tested growth-regulators, oils and seasons.

The results are in harmony with those of Al-Qurashi and Awad (2011) who studied effects of GA3, BA and NAA at different concentrations on the quality characteristics of bisir 'Barhee' dates during cold storage. The concentration of vitamin $\mathrm{C}$ in the GA3-treated fruit at $50 \mathrm{mg} \cdot \mathrm{L}-1$ was lower after 40 days of storage than in control fruit. However, at $150 \mathrm{mg} \mathrm{GA} 3 \cdot \mathrm{L}-1$, it was higher after 60 days of storage than in control fruit. During storage, the concentration of vitamin $\mathrm{C}$ in most treatments including the control tended to increase from day 0 to day 40 and then decreased at day 60 to a level close to the initial level

\section{(e) Total-sugar percent.}

The results in Table (10) showed the effect of growth-regulators "NAA" and "CPPU" dipping in oils and cold-storage duration on totalsugar percent for "Samani" date-fruits in 2019 and 2020 seasons. The total-sugar percent of Samani" date-fruits significantly increased using NAA, CPPU, "NAA, peppermint and lemongrass oils compared with the control treatment (Without growth regulators and without dipping in oils) for all tested concentrations, cold-storage durations and seasons. Also, total-sugar percent significantly increased by increasing NAA, CPPU and peppermint and by decreasing lemongrass oil concentrations for all tested cold-storage durations and seasons. The total-sugar percent of Samani" date-fruits significantly increased by increasing cold-storage duration for all tested growthregulators, oils and seasons.

Results showed that the average totalsugar percent of "Samani" date-fruits using growth regulators", growth regulators + lemongrass oil" and "growth regulators + peppermint oil" were 21.3 - 23.2, $21.0-22.7$ and $21.3-23.0 \%$ respectively for all tested concentrations, coldstorage durations and seasons. 
Table 9: Effect of growth-regulators "NAA" and "CPPU" dipping fruits n oils and coldstorage duration on vitamin $\mathrm{C}$ of "Samani" fruits in 2019 and 2020 seasons.

\begin{tabular}{|c|c|c|c|c|c|c|c|c|c|c|}
\hline \multirow{4}{*}{$\begin{array}{l}\text { A- Growth regulators } \\
\text { (GR) }\end{array}$} & \multicolumn{10}{|c|}{ Vitamin C, mg/100 fw. } \\
\hline & \multicolumn{5}{|c|}{2019} & \multicolumn{5}{|c|}{2020} \\
\hline & \multicolumn{10}{|c|}{ B- Cold-storage duration, (day). } \\
\hline & $\mathbf{0}$ & 15 & 30 & 45 & $\begin{array}{c}\text { Mean } \\
\text { (B) }\end{array}$ & $\mathbf{0}$ & 15 & 30 & 45 & $\begin{array}{c}\text { Mean } \\
\text { (B) }\end{array}$ \\
\hline Control (Water) & 3.17 & 2.79 & 2.46 & 2.12 & 2.64 & 2.81 & 2.54 & 2.31 & 2.09 & 2.44 \\
\hline Water + NAA c1 & 3.86 & 3.54 & 3.2 & 2.83 & 3.36 & 3.51 & 3.17 & 2.8 & 2.48 & 2.99 \\
\hline Water + NAA c2 & 4.19 & 3.85 & 3.49 & 3.17 & 3.68 & 3.81 & 3.45 & 3.13 & 2.79 & 3.30 \\
\hline Water + CPPU c1 & 3.47 & 3.11 & 2.80 & 2.46 & 2.96 & 3.19 & 2.88 & 2.54 & 2.18 & 2.70 \\
\hline Water + CPPU c2 & 3.77 & 3.46 & 3.11 & 2.78 & 3.28 & 3.47 & 3.12 & 2.79 & 2.48 & 2.97 \\
\hline NAA c $1+$ lemongrass $0.4 \%$ & 3.86 & 3.50 & 3.11 & 2.61 & 3.27 & 3.51 & 3.41 & 3.14 & 2.76 & 3.21 \\
\hline NAA c $1+$ lemongrass $0.8 \%$ & 3.86 & 3.52 & 3.42 & 2.90 & 3.43 & 3.51 & 3.79 & 3.41 & 3.07 & 3.45 \\
\hline NAA c $1+$ peppermint $4 \%$ & 3.86 & 3.17 & 2.78 & 2.37 & 3.05 & 3.51 & 3.24 & 2.91 & 2.52 & 3.05 \\
\hline NAA c $1+$ peppermint $8 \%$ & 3.86 & 3.36 & 2.92 & 2.52 & 3.17 & 3.51 & 3.33 & 3.08 & 2.65 & 3.14 \\
\hline NAA c2 + lemongrass $0.4 \%$ & 4.19 & 3.75 & 3.53 & 3.05 & 3.63 & 3.81 & 3.49 & 3.19 & 2.94 & 3.36 \\
\hline NAA c2 + lemongrass $0.8 \%$ & 4.19 & 3.84 & 3.59 & 3.21 & 3.71 & 3.81 & 3.57 & 3.24 & 3.12 & 3.44 \\
\hline NAA c $2+$ peppermint $4 \%$ & 4.19 & 3.60 & 3.16 & 2.72 & 3.42 & 3.81 & 3.32 & 2.93 & 2.65 & 3.18 \\
\hline NAA c $2+$ peppermint $8 \%$ & 4.19 & 3.68 & 3.35 & 2.79 & 3.50 & 3.81 & 3.42 & 3.09 & 2.82 & 3.29 \\
\hline CPPU c1 + lemongrass $0.4 \%$ & 3.47 & 3.22 & 3.08 & 2.64 & 3.10 & 3.19 & 3.02 & 2.9 & 2.61 & 2.93 \\
\hline CPPU c1 + lemongrass $0.8 \%$ & 3.47 & 3.28 & 3.19 & 2.69 & 3.16 & 3.19 & 3.07 & 2.93 & 2.64 & 2.96 \\
\hline CPPU c1 + peppermint $4 \%$ & 3.47 & 3.13 & 2.79 & 2.38 & 2.94 & 3.19 & 2.89 & 2.6 & 2.34 & 2.76 \\
\hline CPPU c1 + peppermint $8 \%$ & 3.47 & 3.19 & 2.84 & 2.42 & 2.98 & 3.19 & 2.94 & 2.64 & 2.38 & 2.79 \\
\hline CPPU c2 + lemongrass $0.4 \%$ & 3.77 & 3.40 & 3.29 & 2.95 & 3.35 & 3.47 & 3.15 & 2.87 & 2.59 & 3.02 \\
\hline CPPU c2 + lemongrass $0.8 \%$ & 3.77 & 3.59 & 3.41 & 3.12 & 3.47 & 3.47 & 3.3 & 3.19 & 2.86 & 3.21 \\
\hline CPPU c $2+$ peppermint $4 \%$ & 3.77 & 3.21 & 2.90 & 2.64 & 3.13 & 3.47 & 2.88 & 2.59 & 2.32 & 2.82 \\
\hline CPPU c $2+$ peppermint $8 \%$ & 3.77 & 3.34 & 3.15 & 2.80 & 3.27 & 3.47 & 3.09 & 2.86 & 2.57 & 3.00 \\
\hline Mean (A) & 3.82 & 3.44 & 3.16 & 2.75 & & 3.50 & 3.23 & 2.94 & 2.64 & \\
\hline LSD at 0.05 & \multicolumn{5}{|c|}{$\begin{array}{l}\text { Growth regulators (GR): } 0.04 \\
\text { Storage periods (B): } 0.02\end{array}$} & \multicolumn{5}{|c|}{$\begin{array}{l}\text { Growth regulators (GR): } 0.04 \\
\text { Storage periods }(\text { B): } 0.02\end{array}$} \\
\hline $\begin{array}{l}\text { c1: }(80 \mathrm{mg} / \mathrm{l} \text { at hababak s } \\
\text { c2: }(90 \mathrm{mg} / \mathrm{l} \text { at hababak s } \\
\text { c1: }(5 \mathrm{mg} / \mathrm{l} \text { at hababak st } \\
\text { c2: }(10 \mathrm{mg} / \mathrm{l} \text { at hababak }\end{array}$ & 5 & & 1 & ing & 9 & rats & & & & \\
\hline
\end{tabular}


Table 10: Effect of growth-regulators "NAA" and "CPPU" dipping fruits n oils and coldstorage duration on total-sugar percent of "Samani" fruits in 2019 and 2020 seasons.

\begin{tabular}{|c|c|c|c|c|c|c|c|c|c|c|}
\hline \multirow{4}{*}{$\begin{array}{l}\text { A- Growth regulators } \\
\text { (GR) }\end{array}$} & \multicolumn{10}{|c|}{ Total sugar, $\%$. } \\
\hline & \multicolumn{5}{|c|}{2019} & \multicolumn{5}{|c|}{2020} \\
\hline & \multicolumn{10}{|c|}{ B- Cold-storage duration, (day). } \\
\hline & $\mathbf{0}$ & 15 & 30 & 45 & $\begin{array}{c}\text { Mean } \\
\text { (B) }\end{array}$ & $\mathbf{0}$ & 15 & 30 & 45 & $\begin{array}{c}\text { Mean } \\
\text { (B) }\end{array}$ \\
\hline Control (Water) & 15.8 & 16.4 & 17.9 & 18.8 & 17.2 & 17.3 & 17.8 & 18.8 & 19.7 & 18.4 \\
\hline Water + NAA c1 & 21.9 & 22.9 & 23.8 & 24.8 & 23.3 & 19.9 & 20.8 & 21.8 & 22.9 & 21.3 \\
\hline Water + NAA c2 & 23.7 & 24.8 & 25.9 & 26.9 & 25.3 & 21.7 & 22.8 & 23.9 & 25.0 & 23.4 \\
\hline Water + CPPU c1 & 19.7 & 20.7 & 21.8 & 23.0 & 21.3 & 17.9 & 19.0 & 20.1 & 21.2 & 19.6 \\
\hline Water + CPPU c2 & 21.3 & 22.3 & 23.2 & 24.2 & 22.8 & 19.4 & 20.4 & 21.4 & 22.3 & 20.9 \\
\hline NAA c1 + lemongrass $0.4 \%$ & 21.9 & 22.6 & 23.5 & 24.4 & 23.1 & 19.9 & 20.6 & 21.4 & 22.2 & 21.0 \\
\hline NAA c1 + lemongrass 0.8 & 21.9 & 22.4 & 23.2 & 24.2 & 22.9 & 19.9 & 20.5 & 21.2 & 22.0 & 20.9 \\
\hline NAA c $1+$ peppermint $4 \%$ & 21.9 & 22.8 & 23.8 & 24.7 & 23.3 & 19.9 & 20.7 & 21.6 & 22.4 & 21.1 \\
\hline NAA c $1+$ peppermint $8 \%$ & 21.9 & 22.9 & 23.9 & 24.8 & 23.4 & 19.9 & 20.8 & 21.6 & 22.5 & 21.2 \\
\hline NAA c2 + lemongrass $0.4 \%$ & 23.7 & 24.3 & 25.2 & 25.9 & 24.8 & 21.7 & 22.6 & 23.4 & 24.1 & 22.9 \\
\hline NAA c2 + lemongrass 0.8 & 23.7 & 24.2 & 24.9 & 25.3 & 24.5 & 21.7 & 22.3 & 23.2 & 23.8 & 22.8 \\
\hline NAA c $2+$ peppermint $4 \%$ & 23.7 & 24.5 & 25.3 & 26.0 & 24.8 & 21.7 & 22.7 & 23.6 & 24.2 & 23.1 \\
\hline NAA c $2+$ peppermint $8 \%$ & 23.7 & 24.6 & 25.6 & 26.5 & 25.1 & 21.7 & 23.0 & 23.9 & 24.6 & 23.3 \\
\hline CPPU c $1+$ lemongrass $0.4 \%$ & 19.7 & 20.4 & 21.3 & 22.2 & 20.9 & 17.9 & 18.6 & 19.5 & 20.4 & 19.1 \\
\hline CPPU c $1+$ lemongrass 0.8 & 19.7 & 20.2 & 21.0 & 21.9 & 20.7 & 17.9 & 18.4 & 19.1 & 20.0 & 18.9 \\
\hline CPPU c1 + peppermint $4 \%$ & 19.7 & 20.6 & 21.5 & 22.6 & 21.1 & 17.9 & 18.8 & 19.8 & 20.6 & 19.3 \\
\hline CPPU $\mathrm{c} 1+$ peppermint $8 \%$ & 19.7 & 20.7 & 21.8 & 22.7 & 21.2 & 17.9 & 18.9 & 20.0 & 20.8 & 19.4 \\
\hline CPPU c2 + lemongrass $0.4 \%$ & 21.3 & 22.1 & 23.0 & 23.9 & 22.6 & 19.4 & 20.2 & 20.9 & 21.8 & 20.6 \\
\hline CPPU c2 + lemongrass 0.8 & 21.3 & 21.8 & 22.7 & 23.5 & 22.3 & 19.4 & 19.9 & 20.6 & 21.5 & 20.4 \\
\hline CPPU c $2+$ peppermint $4 \%$ & 21.3 & 22.2 & 23.3 & 24.0 & 22.7 & 19.4 & 20.3 & 21.0 & 21.9 & 20.7 \\
\hline CPPU c $2+$ peppermint $8 \%$ & 21.3 & 22.3 & 23.4 & 24.1 & 22.8 & 19.4 & 20.4 & 21.5 & 22.2 & 20.9 \\
\hline Mean $(\mathrm{A})$ & 21.6 & 22.5 & 23.4 & 24.3 & & 19.7 & 20.6 & 21.5 & 22.3 & \\
\hline LSD at 0.05 & $\begin{array}{l}\text { Grov } \\
\text { Stora }\end{array}$ & $\begin{array}{l}\text { th } \\
\text { ge peri } \\
\end{array}$ & $\begin{array}{l}\text { ulator } \\
\text { ds (B) }\end{array}$ & $\begin{array}{r}\text { (GF } \\
0.18 \\
\end{array}$ & $\mathbf{0 . 3 8}$ & $\begin{array}{l}\text { Grow } \\
\text { Stora }\end{array}$ & $\begin{array}{l}\text { th re } \\
\text { ge peri }\end{array}$ & $\begin{array}{l}\text { sulator } \\
\text { ods (B) }\end{array}$ & $\begin{array}{l}\text { (GR } \\
0.17 \\
\end{array}$ & 0.34 \\
\hline $\begin{array}{l}\text { c1: }(80 \mathrm{mg} / \mathrm{l} \text { at hababak sta } \\
\text { c2: }(90 \mathrm{mg} / \mathrm{l} \text { at hababak sta } \\
\mathrm{U} \text { c1: }(5 \mathrm{mg} / \mathrm{l} \text { at hababak stag } \\
\mathrm{U} \text { c2: }(10 \mathrm{mg} / \mathrm{l} \text { at hababak st } \\
\text { entages beside lemongrass an }\end{array}$ & $\mathrm{m}$ & 2 & ? & 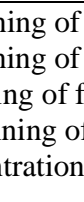 & t co & break & & & & \\
\hline
\end{tabular}

It was found that by increasing coldstorage duration from zero to 45 days the average of total-sugar percent of "Samani fruits increased from $19.7-21.6$ to $22.3-24.3 \%$ for all tested growth-regulators, oils and seasons.

The results are in harmony with those of El-Hadidy et al. (2015) who studied the effect of some postharvest treatments: paraffin, lemongrass oils and low density polyethylene bags (LDPE) on fruit quality attributes of Om El-Ferakh date fruits during cold storage. It was found that all the used treatments greatly increased fruit total sugar content of dates during cold storage as compared to control in both seasons. However, lemon grass oil treatment exhibited the highest total sugars than other treatments. It increased during storage period from 0 to 14 days, and then decreased after 21 days.
Regarding the interaction between the effect of treatments and storage period, at $5{ }^{\circ} \mathrm{C}$ and $90 \%$ $\mathrm{RH}$, the highest value of total sugars was recorded by lemongrass oil while, control fruits recorded the lowest value of total sugars in both seasons. ElSharony et al. (2015) investigated the efficiency of using some natural substances i.e. Arabic gum at $10 \%$, black cumin (Nigella sativa) oil at $1 \%$ as well as their combination besides untreated fruits as a control under colds storage on two date palm fruits cvs. Zaghloul and Samani harvested at full coloured stage (khalal). It was found that the averages of Zaghloul and Samani fruit total sugar increased using all treatments comparing with control treatment. Similarly, Abd El-Motty, (1995) showed an increase of total sugars \% in 
"Sewi" dates obtained with naturally or artificially ripening process.

(f) Tannins percent.

Table (11) shows the effect of growthregulators "NAA" and "CPPU" dipping in oils and cold-storage duration on tannins percent for "Samani" date-fruits in 2019 and 2020 seasons. The tannins percent of Samani" date-fruits significantly decreased using NAA, CPPU, "NAA, peppermint and lemongrass oils compared with the control treatment (Without growth regulators and without dipping in oils) for all tested concentrations, cold-storage durations and seasons. Also, tannins percent significantly decreased by increasing NAA, CPPU and peppermint and by decreasing lemongrass oil concentrations for all tested cold-storage durations and

seasons.

The tannins percent of Samani" date-fruits significantly decreased by increasing cold-storage duration for all tested growth-regulators, oils and seasons.

Results show that the average tannins percent of "Samani" date-fruits using growth regulators", growth regulators + lemongrass oil" and "growth regulators + peppermint oil" were $0.35-0.37,0.35-0.39$ and $0.33-0.37 \%$ respectively for all tested concentrations, coldstorage durations and seasons.

Tables 11: Effect of growth-regulators "NAA" and "CPPU" dipping fruits n oils and coldstorage duration on tannins percent of "Samani" fruits in 2019 and 2020 seasons.

\begin{tabular}{|c|c|c|c|c|c|c|c|c|c|c|}
\hline \multirow{4}{*}{$\begin{array}{l}\text { A- Growth regulators } \\
\text { (GR) }\end{array}$} & \multicolumn{10}{|c|}{ Tannins, \%. } \\
\hline & \multicolumn{5}{|c|}{2019} & \multicolumn{5}{|c|}{2020} \\
\hline & \multicolumn{10}{|c|}{ B- Cold-storage duration, (day). } \\
\hline & $\mathbf{0}$ & 15 & 30 & 45 & $\begin{array}{c}\text { Mean } \\
(\text { B })\end{array}$ & $\mathbf{0}$ & 15 & 30 & 45 & $\begin{array}{c}\text { Mean } \\
(\text { B })\end{array}$ \\
\hline Control (Water) & 0.62 & 0.49 & 0.44 & 0.39 & 0.49 & 0.65 & 0.58 & 0.52 & 0.44 & 0.55 \\
\hline Water + NAA c1 & 0.45 & 0.36 & 0.28 & 0.20 & 0.32 & 0.48 & 0.40 & 0.32 & 0.24 & 0.36 \\
\hline Water + NAA c2 & 0.41 & 0.33 & 0.26 & 0.17 & 0.29 & 0.43 & 0.32 & 0.25 & 0.16 & 0.29 \\
\hline Water + CPPU c1 & 0.56 & 0.46 & 0.37 & 0.26 & 0.41 & 0.59 & 0.50 & 0.41 & 0.30 & 0.45 \\
\hline Water + CPPU c2 & 0.51 & 0.40 & 0.32 & 0.22 & 0.36 & 0.53 & 0.42 & 0.34 & 0.24 & 0.38 \\
\hline NAA c $1+$ lemongrass $0.4 \%$ & 0.45 & 0.35 & 0.29 & 0.19 & 0.32 & 0.48 & 0.37 & 0.29 & 0.19 & 0.33 \\
\hline NAA c1 + lemongrass 0.8 & 0.45 & 0.36 & 0.28 & 0.19 & 0.32 & 0.48 & 0.38 & 0.29 & 0.20 & 0.34 \\
\hline NAA c $1+$ peppermint $4 \%$ & 0.45 & 0.33 & 0.27 & 0.17 & 0.31 & 0.48 & 0.35 & 0.27 & 0.18 & 0.32 \\
\hline NAA c $1+$ peppermint $8 \%$ & 0.45 & 0.34 & 0.27 & 0.18 & 0.31 & 0.48 & 0.36 & 0.27 & 0.18 & 0.32 \\
\hline NAA c2 + lemongrass $0.4 \%$ & 0.41 & 0.32 & 0.25 & 0.16 & 0.29 & 0.43 & 0.33 & 0.24 & 0.16 & 0.29 \\
\hline NAA c2 + lemongrass 0.8 & 0.41 & 0.32 & 0.26 & 0.17 & 0.29 & 0.43 & 0.34 & 0.25 & 0.17 & 0.30 \\
\hline NAA c $2+$ peppermint $4 \%$ & 0.41 & 0.29 & 0.24 & 0.14 & 0.27 & 0.43 & 0.3 & 0.22 & 0.14 & 0.27 \\
\hline NAA c $2+$ peppermint $8 \%$ & 0.41 & 0.30 & 0.25 & 0.16 & 0.28 & 0.43 & 0.31 & 0.23 & 0.15 & 0.28 \\
\hline CPPU c1 + lemongrass $0.4 \%$ & 0.56 & 0.45 & 0.38 & 0.26 & 0.41 & 0.59 & 0.48 & 0.39 & 0.28 & 0.44 \\
\hline CPPU c $1+$ lemongrass 0.8 & 0.56 & 0.48 & 0.40 & 0.29 & 0.43 & 0.59 & 0.52 & 0.41 & 0.31 & 0.46 \\
\hline CPPU c1 + peppermint $4 \%$ & 0.56 & 0.40 & 0.33 & 0.22 & 0.38 & 0.59 & 0.42 & 0.33 & 0.24 & 0.40 \\
\hline CPPU c1 + peppermint $8 \%$ & 0.56 & 0.42 & 0.34 & 0.25 & 0.39 & 0.59 & 0.45 & 0.35 & 0.26 & 0.41 \\
\hline CPPU c2 + lemongrass $0.4 \%$ & 0.51 & 0.38 & 0.31 & 0.21 & 0.35 & 0.53 & 0.41 & 0.31 & 0.22 & 0.37 \\
\hline CPPU c2 + lemongrass 0.8 & 0.51 & 0.40 & 0.33 & 0.22 & 0.37 & 0.53 & 0.42 & 0.33 & 0.24 & 0.38 \\
\hline CPPU c $2+$ peppermint $4 \%$ & 0.51 & 0.37 & 0.29 & 0.20 & 0.34 & 0.53 & 0.39 & 0.3 & 0.21 & 0.36 \\
\hline CPPU c $2+$ peppermint $8 \%$ & 0.51 & 0.37 & 0.30 & 0.21 & 0.35 & 0.53 & 0.4 & 0.3 & 0.21 & 0.36 \\
\hline Mean (A) & 0.48 & 0.37 & 0.30 & 0.20 & & 0.51 & 0.39 & 0.31 & 0.21 & \\
\hline LSD & \multicolumn{5}{|c|}{$\begin{array}{l}\text { Growth regulators (GR): } 0.010 \\
\text { Storage periods (B): } 0.004\end{array}$} & \multicolumn{4}{|c|}{$\begin{array}{l}\text { Growth regulators (GR): } \\
\text { Storage periods }(\mathrm{B}): 0.004\end{array}$} & 0.010 \\
\hline \multicolumn{11}{|c|}{$\begin{array}{l}\text { NAA c1: }(80 \mathrm{mg} / \mathrm{l} \text { at hababak stage and } 50 \mathrm{mg} / \mathrm{l} \text { at the beginning of fruit color break). } \\
\text { NAA c2: ( } 90 \mathrm{mg} / \mathrm{l} \text { at hababak stage and } 60 \mathrm{mg} / 1 \text { at the beginning of fruit color break). } \\
\text { CPPU c1: ( } 5 \mathrm{mg} / \mathrm{l} \text { at hababak stage and } 10 \mathrm{mg} / \mathrm{l} \text { at the beginning of fruit color break). } \\
\text { CPPU c2: ( } 10 \mathrm{mg} / \mathrm{l} \text { at hababak stage and } 15 \mathrm{mg} / \mathrm{l} \text { at the beginning of fruit color break). } \\
\text { Percentages beside lemongrass and peppermint are oil concentrations. }\end{array}$} \\
\hline
\end{tabular}


It was found that by increasing coldstorage duration from zero to 45 days the average of tannins percent of "Samani fruits decreased from $0.48-0.51$ to $0.20-0.21 \%$ for all tested growth-regulators, oils and seasons.

The results are in harmony with those of Zaki et al. (2017) who investigated the effect of some postharvest natural extracts i.e., green tea at $2 \%$, fenugreek seeds at $0.5 \%$ and jasmine oil at $200 \mathrm{ppm}$ on date palm fruits $\mathrm{cv}$. 'Zaghloul' as solely or mixed dipping treatments under cold storage conditions $(0 \pm$ $1{ }^{\circ} \mathrm{C}$ with R. H. $\left.85-90 \%\right)$ for 60 days compared with control fruit (water only). They found that the percentage of tannins content decreased by increasing storage period, Yehia and Zaki (2020) studied the effect of a mechanical pollination on quality of "Zaghloul" Date-palm fruits during cold storage. They found that by increasing coldstorage period of Zaghloul fruits from 0 to 60 days the tannins content decreased. Al-Ogaidi and Mutlak (1986), Abu-Goukh et al. (2003) and Al-Redhaiman (2004) reported that tannin contents of different date fruit cultivars were at maximum concentration in the Khalal (Bisr) stage (full mature stage of development) and gradually decreased to reach a minimum concentration in the ripe stage (Rutab) during cold storage. Abd ElMotty (1995) found that soluble form of tannins convert into insoluble ones during Rutab stage. They also added that high content of soluble and insoluble forms of tannins might protect fruits at this stage (Rutab) because such oxidized phenols are more active as antifungal agent than oxidized materials. Moreover, total sugars, total acidity, total phenols and total tannins support the taste balance which distinguished each variety than others.

\section{(g) Chlorophyll.}

Table (12) shows the effect of growthregulators "NAA" and "CPPU" dipping in oils and cold-storage duration on chlorophyll for "Samani" date-fruits in 2019 and 2020 seasons. The chlorophyll of Samani" datefruits significantly increased using NAA, CPPU, "NAA, peppermint and lemongrass oils compared with the control treatment (Without growth regulators and without dipping in oils) for all tested concentrations, cold-storage durations and seasons. Also, chlorophyll significantly increased by increasing NAA, CPPU and peppermint and lemongrass oil concentrations for all tested cold-storage durations and seasons. The chlorophyll of Samani" date-fruits significantly decreased by increasing coldstorage duration for all tested growthregulators, oils and seasons.

Results show that the average chlorophyll of "Samani" date-fruits using growth regulators, "growth regulators + lemongrass oil" and "growth regulators + peppermint oil" were $8.2-6.9,7.0-8.5$ and $6.9-8.4 \mathrm{mg} / 100 \mathrm{~g}$ respectively for all tested concentrations, cold-storage durations and seasons. 
Tables 12: Effect of growth-regulators "NAA" and "CPPU" dipping fruits $n$ oils and coldstorage duration on chlorophyll of "Samani" fruits in 2019 and 2020 seasons.

\begin{tabular}{|c|c|c|c|c|c|c|c|c|c|c|}
\hline \multirow{4}{*}{$\begin{array}{l}\text { A- Growth regulators } \\
\text { (GR) }\end{array}$} & \multicolumn{10}{|c|}{ Chlorophyll, mg/100g. } \\
\hline & \multicolumn{5}{|l|}{2019} & \multicolumn{5}{|l|}{2020} \\
\hline & \multicolumn{10}{|c|}{ B- Cold-storage duration, (day). } \\
\hline & $\mathbf{0}$ & 15 & 30 & 45 & $\begin{array}{l}\text { Mean } \\
\text { (B) }\end{array}$ & $\mathbf{0}$ & 15 & 30 & 45 & $\begin{array}{l}\text { Mean } \\
\text { (B) }\end{array}$ \\
\hline Control (Water) & 6.9 & 5.6 & 4.6 & 3.7 & 5.2 & 7.8 & 6.4 & 5.6 & 4.6 & 6.1 \\
\hline Water + NAA c1 & 9.5 & 7.8 & 5.9 & 4.5 & 6.9 & 10.5 & 9.0 & 7.3 & 6.7 & 8.4 \\
\hline Water + NAA c2 & 10.1 & 8.0 & 6.3 & 5.1 & 7.4 & 11.2 & 10.3 & 8.8 & 6.7 & 9.3 \\
\hline Water + CPPU c1 & 8.9 & 7.5 & 5.4 & 4.3 & 6.5 & 9.7 & 8.5 & 5.8 & 5.2 & 7.3 \\
\hline Water + CPPU c2 & 9.3 & 7.7 & 5.8 & 4.7 & 6.9 & 10.2 & 8.7 & 6.3 & 5.5 & 7.7 \\
\hline NAA c $1+$ lemongrass $0.4 \%$ & 9.5 & 7.9 & 6.0 & 4.6 & 7.0 & 10.5 & 9.1 & 7.4 & 6.8 & 8.5 \\
\hline NAA c1 + lemongrass 0.8 & 9.5 & 8.0 & 6.1 & 4.7 & 7.1 & 10.5 & 9.1 & 7.4 & 6.9 & 8.5 \\
\hline NAA c1 + peppermint $4 \%$ & 9.5 & 7.8 & 5.9 & 4.4 & 6.9 & 10.5 & 9.0 & 7.2 & 6.6 & 8.3 \\
\hline NAA c1 + peppermint $8 \%$ & 9.5 & 7.8 & 6.0 & 4.5 & 7.0 & 10.5 & 9.0 & 7.3 & 6.7 & 8.4 \\
\hline NAA c2 + lemongrass $0.4 \%$ & 10.1 & 8.1 & 6.4 & 5.2 & 7.5 & 11.2 & 10.4 & 8.9 & 6.8 & 9.3 \\
\hline NAA c2 + lemongrass 0.8 & 10.1 & 8.2 & 6.5 & 5.3 & 7.5 & 11.2 & 10.5 & 9.0 & 7.0 & 9.4 \\
\hline NAA c $2+$ peppermint $4 \%$ & 10.1 & 8.0 & 6.4 & 5.0 & 7.4 & 11.2 & 10.3 & 8.9 & 6.6 & 9.2 \\
\hline NAA c $2+$ peppermint $8 \%$ & 10.1 & 8.1 & 6.4 & 5.1 & 7.4 & 11.2 & 10.3 & 8.9 & 6.7 & 9.3 \\
\hline CPPU c1 + lemongrass $0.4 \%$ & 8.9 & 7.6 & 5.5 & 4.4 & 6.6 & 9.7 & 8.6 & 5.9 & 5.3 & 7.4 \\
\hline CPPU c1 + lemongrass 0.8 & 8.9 & 7.7 & 5.6 & 4.6 & 6.7 & 9.7 & 8.7 & 5.9 & 5.5 & 7.5 \\
\hline CPPU c1 + peppermint $4 \%$ & 8.9 & 7.5 & 5.4 & 4.1 & 6.5 & 9.7 & 8.4 & 5.7 & 5.0 & 7.2 \\
\hline CPPU c1 + peppermint $8 \%$ & 8.9 & 7.6 & 5.5 & 4.3 & 6.5 & 9.7 & 8.5 & 5.7 & 5.2 & 7.3 \\
\hline CPPU c2 + lemongrass $0.4 \%$ & 9.3 & 7.8 & 5.9 & 4.8 & 6.9 & 10.2 & 8.8 & 6.4 & 5.6 & 7.8 \\
\hline CPPU c2 + lemongrass 0.8 & 9.3 & 7.8 & 5.9 & 4.9 & 7.0 & 10.2 & 8.9 & 6.5 & 5.8 & 7.8 \\
\hline CPPU c $2+$ peppermint $4 \%$ & 9.3 & 7.7 & 5.8 & 4.6 & 6.8 & 10.2 & 8.7 & 6.3 & 5.4 & 7.6 \\
\hline CPPU c2 + peppermint $8 \%$ & 9.3 & 7.7 & 5.8 & 4.7 & 6.9 & 10.2 & 8.7 & 6.3 & 5.5 & 7.7 \\
\hline Mean (A) & 9.5 & 7.8 & 5.9 & 4.7 & & 10.4 & 9.2 & 7.1 & 6.1 & \\
\hline LSD at 0.05 & $\begin{array}{l}\text { Grov } \\
\text { Stor }\end{array}$ & $\begin{array}{l}\text { h r } \\
\text { e pe }\end{array}$ & ds ( & $\begin{array}{r}G \\
0.03 \\
\end{array}$ & 0.06 & $\begin{array}{l}\text { Grov } \\
\text { Stor: }\end{array}$ & $\begin{array}{l}\text { th } \mathrm{rc} \\
\text { ge per }\end{array}$ & ulat & (G) & 0.09 \\
\hline
\end{tabular}

NAA c1: $(80 \mathrm{mg} / \mathrm{l}$ at hababak stage and $50 \mathrm{mg} / \mathrm{l}$ at the beginning of fruit color break).

NAA c2: $(90 \mathrm{mg} / \mathrm{l}$ at hababak stage and $60 \mathrm{mg} / \mathrm{l}$ at the beginning of fruit color break).

CPPU c1: ( $5 \mathrm{mg} / \mathrm{l}$ at hababak stage and $10 \mathrm{mg} / \mathrm{l}$ at the beginning of fruit color break).

CPPU c2: $(10 \mathrm{mg} / \mathrm{l}$ at hababak stage and $15 \mathrm{mg} / \mathrm{l}$ at the beginning of fruit color break).

Percentages beside lemongrass and peppermint are oil concentrations.

It was found that by increasing coldstorage duration from zero to 45 days the average chlorophyll of "Samani fruits decreased from $9.5-10.4$ to $4.7-6.1$ $\mathrm{mg} / 100 \mathrm{~g}$ for all tested growth-regulators, oils and seasons.

The increase in fruit total chlorophyllcontent obtained using NAA, GA3 and CPPU application might be due to their influence in retarding fruit ripening process as mentioned before by (Hussein et al 1996; Moustafa et al 1996; Moustafa and Seif 1996; Aljuburi et al 2000) working on date palm fruit.

(h) Carotene.

Table (13) shows the effect of growthregulators "NAA" and "CPPU" dipping in oils and cold-storage duration on carotene for "Samani" date-fruits in 2019 and 2020 seasons. The carotene of Samani" date-fruits significantly decreased using NAA, CPPU, "NAA, peppermint and lemongrass oils compared with the control treatment (Without growth regulators and without dipping in oils) for all tested concentrations, cold-storage durations and seasons. Also, carotene significantly increased by increasing NAA, CPPU and peppermint and by decreasing lemongrass oil concentrations for all tested cold-storage durations and seasons. The carotene of Samani" date-fruits significantly increased by increasing cold- 
storage duration for all tested growthregulators, oils and seasons.

Results showed that the average carotene of "Samani" date-fruits using growth regulators, "growth regulators + lemongrass oil" and "growth regulators + peppermint oil" were $4.23-4.42,4.14-4.45$ and $4.33-4.58$ $\mathrm{mg} / 100 \mathrm{~g}$ respectively for all tested concentrations, cold-storage durations and seasons.

It was found that by increasing coldstorage duration from zero to 45 days the average carotene of "Samani fruits increased from $3.6-3.9$ to $4.9-5.1 \mathrm{mg} / 100 \mathrm{~g}$ for all tested growth-regulators, oils and seasons.

The decrease in fruit carotene-content obtained using NAA, GA3 and CPPU application might be due to their influence in retarding fruit ripening process as mentioned before by (Hussein et al 1996; Moustafa et al 1996; Moustafa and Seif 1996; Aljuburi et al 2000).

Tables 13: Effect of growth-regulators "NAA" and "CPPU" dipping fruits $n$ oils and coldstorage duration on carotene of "Samani" fruits in 2019 and 2020 seasons.

\begin{tabular}{|c|c|c|c|c|c|c|c|c|c|c|}
\hline \multirow{4}{*}{$\begin{array}{c}\text { A- Growth regulators } \\
\text { (GR) }\end{array}$} & \multicolumn{10}{|c|}{ Carotene, mg/100g. } \\
\hline & \multicolumn{5}{|c|}{2019} & \multicolumn{5}{|c|}{2020} \\
\hline & \multicolumn{10}{|c|}{ B- Cold-storage duration, (day). } \\
\hline & $\mathbf{0}$ & 15 & 30 & 45 & $\begin{array}{c}\text { Mean } \\
\text { (B) }\end{array}$ & $\mathbf{0}$ & 15 & 30 & 45 & $\begin{array}{c}\text { Mean } \\
\text { (B) }\end{array}$ \\
\hline Control (Water) & 4.8 & 5.2 & 5.5 & 5.9 & 5.4 & 4.6 & 5.0 & 5.5 & 5.8 & 5.2 \\
\hline Water + NAA c1 & 4.2 & 4.7 & 5.1 & 5.4 & 4.8 & 3.8 & 4.3 & 4.7 & 5.1 & 4.5 \\
\hline Water + NAA c2 & 4.5 & 4.8 & 5.2 & 5.7 & 5.1 & 4.1 & 4.5 & 5.1 & 5.4 & 4.8 \\
\hline Water + CPPU c1 & 3.4 & 3.6 & 3.9 & 4.2 & 3.8 & 3.1 & 3.6 & 3.9 & 4.3 & 3.7 \\
\hline Water + CPPU c2 & 3.5 & 3.8 & 4.2 & 4.6 & 4.0 & 3.3 & 3.8 & 4.1 & 4.5 & 3.9 \\
\hline NAA c 1 + lemongrass $0.4 \%$ & 4.2 & 4.8 & 5.2 & 5.5 & 4.9 & 3.8 & 4.4 & 4.8 & 5.2 & 4.6 \\
\hline NAA c 1 + lemongrass $0.8 \%$ & 4.2 & 4.6 & 5.0 & 5.3 & 4.8 & 3.8 & 4.2 & 4.6 & 5.0 & 4.4 \\
\hline NAA c $1+$ peppermint $4 \%$ & 4.2 & 4.9 & 5.2 & 5.5 & 4.9 & 3.8 & 4.6 & 4.9 & 5.3 & 4.6 \\
\hline NAA c $1+$ peppermint $8 \%$ & 4.2 & 5.0 & 5.5 & 5.9 & 5.1 & 3.8 & 4.7 & 5.1 & 5.5 & 4.8 \\
\hline NAA c $2+$ lemongrass $0.4 \%$ & 4.5 & 4.9 & 5.3 & 5.8 & 5.1 & 4.1 & 4.6 & 5.2 & 5.5 & 4.9 \\
\hline NAA c2 + lemongrass $0.8 \%$ & 4.5 & 4.8 & 5.2 & 5.6 & 5.0 & 4.1 & 4.5 & 4.9 & 5.3 & 4.7 \\
\hline NAA c $2+$ peppermint $4 \%$ & 4.5 & 4.9 & 5.4 & 5.9 & 5.2 & 4.1 & 4.7 & 5.4 & 5.6 & 5.0 \\
\hline NAA c $2+$ peppermint $8 \%$ & 4.5 & 5.0 & 5.6 & 6.2 & 5.3 & 4.1 & 4.8 & 5.5 & 5.7 & 5.0 \\
\hline CPPU c $1+$ lemongrass $0.4 \%$ & 3.4 & 3.7 & 4.0 & 4.3 & 3.9 & 3.1 & 3.7 & 4.0 & 4.4 & 3.8 \\
\hline CPPU c1 + lemongrass $0.8 \%$ & 3.4 & 3.6 & 4.0 & 4.3 & 3.8 & 3.1 & 3.5 & 3.9 & 4.3 & 3.7 \\
\hline CPPU c $1+$ peppermint $4 \%$ & 3.4 & 3.7 & 4.1 & 4.4 & 3.9 & 3.1 & 3.9 & 4.3 & 4.6 & 4.0 \\
\hline CPPU c $1+$ peppermint $8 \%$ & 3.4 & 3.8 & 4.2 & 4.5 & 3.9 & 3.1 & 3.9 & 4.3 & 4.6 & 4.0 \\
\hline CPPU c2 + lemongrass $0.4 \%$ & 3.5 & 3.9 & 4.3 & 4.7 & 4.1 & 3.3 & 3.9 & 4.2 & 4.6 & 4.0 \\
\hline CPPU c2 + lemongrass 0.8 & 3.5 & 3.8 & 4.2 & 4.6 & 4.0 & 3.3 & 3.6 & 4.0 & 4.4 & 3.8 \\
\hline CPPU c $2+$ peppermint $4 \%$ & 3.5 & 3.9 & 4.3 & 4.7 & 4.1 & 3.3 & 4.0 & 4.4 & 4.8 & 4.1 \\
\hline CPPU c2 + peppermint $8 \%$ & 3.5 & 4.0 & 4.4 & 4.8 & 4.1 & 3.3 & 4.2 & 4.6 & 4.9 & 4.2 \\
\hline Mean $(\mathrm{A})$ & 3.9 & 4.3 & 4.7 & 5.1 & & 3.6 & 4.2 & 4.6 & 4.9 & \\
\hline LSD at 0.05 & $\begin{array}{l}\text { Grov } \\
\text { Stor: }\end{array}$ & per & $\begin{array}{l}\text { ulator } \\
\text { iods (1) }\end{array}$ & $\begin{array}{l}S \text { (GF } \\
\text { ): } 0 .\end{array}$ & $\begin{array}{l}: 0.06 \\
04\end{array}$ & $\begin{array}{l}\text { Gro } \\
\text { Stor }\end{array}$ & & & $\begin{array}{l}\text { S (GR } \\
\text { ): } 0.0\end{array}$ & \\
\hline
\end{tabular}

NAA c1: (80 mg/l at hababak stage and $50 \mathrm{mg} / \mathrm{l}$ at the beginning of fruit color break).

NAA c2: (90 mg/l at hababak stage and $60 \mathrm{mg} / \mathrm{l}$ at the beginning of fruit color break).

CPPU c1: ( $5 \mathrm{mg} / \mathrm{l}$ at hababak stage and $10 \mathrm{mg} / \mathrm{l}$ at the beginning of fruit color break).

CPPU c2: (10 mg/l at hababak stage and $15 \mathrm{mg} / \mathrm{l}$ at the beginning of fruit color break).

Lemongrass and peppermint oil concentrations. 


\section{CONCLUSION}

Yield components and fruit physical and chemical characteristics of "Samani" dates were improved by spraying NAA and CPPU growth regulators.

The best growth regulator which gave the suitable yield and physical and chemical characteristics of "Samani" dates was obtained by NAA " $90 \mathrm{mg} / \mathrm{l}$ at hababak stage and $60 \mathrm{mg} / \mathrm{l}$ at the beginning of fruit color break

The best "Samani" date-palm fruitquality using the optimum growth regulator of NAA " $90 \mathrm{mg} / \mathrm{l}$ at hababak stage and $60 \mathrm{mg} / \mathrm{l}$ at the beginning of fruit color break" was obtained using fruit dipping in $8 \%$ peppermint oil at cold storage conditions of " $0 \pm 1{ }^{\circ} \mathrm{C}$ with R. H. $85-90 \%$ " for the best duration of 45 days.

\section{REFERENCES}

Abd El-Motty and Elham, Z. (1995) Physiological studies on ripening and storage of dates M.Sc. Thesis, Faculty of Agriculture, Ain shams University, Egypt.

Aboutalebi, A. and Beharoznam, B. (2006) Study on the effects of plant growth regulators on date fruit characteristics, International conference on date palm production and processing technology, book of abstracts. pp. 9-11, Muscat, Oman

Adato, I. and Gazit, S. (1974) Water-deficit stress, ethylene production, and ripening in avocado fruits, Plant Physiol. 53:45-46.

Agusti, M., Gariglio, N., Castillo, A., Juan, M., Almela, V., Martinez-Fuentes, A. and Mesejo, C. (2003) Effect of the synthtic auxin 2,4-DP on fruit development of loquat, Plant Growth Regul., 41, 129-132.

Ahmed M.A., Hassan, H. S. A. and Soliman, S. S. (2010) Effect of some growth regulators on yield and fruit quality of Samani date palm. Acta Hort. (ISHI) 882: 745- 754.

Aleid, S. M., Elansari, A. M., Tang, Z. X. and Sallam, A. A. (2014) Effect of cold storage and packin type on khalas and sukkary dates quality. Adv. J. Food Sci. Technol., 6 (5): 603-608.

Aljuburi, H. J, Al-Masry, H. and AlMuhanna S. A. (2000) Fruit characteristics and productivity of date palm trees (Phoenix dactylifera L.) as affected by some growth regulators, Hortscience 35:476-477.

Al-Kahtani, H. A., Abu-Tarboush, H. M., Al-Dryhim, Y. N., Ahmed, M. A., Bajaber, A. S., El-Shami, E. A. and ElMojaddidi, M. A. (1998) Irradiation of dates: Insect disinfestations, microbial and chemical assessments and use of thermos luminescence. Radiat. Phys.Chem., 53: 181-187.

Al-Obeed, R. S. (2010) Improving fruit quality, marketability and storability of Barhee Date palm, World Applied Sci. J., 9 (6): 630-637.

A.O.A.C. (2000) Association of Official Agriculture Chemist. Official method of analysis, $17^{\text {th }}$ Ed., Washington, D.C. U.S.A: 490-520.

Awad, M. A. and Al-Qurashi, A. D. (2012) Gibberellic acid spray and bunch bagging increase bunch weight and improve fruit quality of Barhee" date palm cultivar under hot arid conditions, Sci. Hort., 138, 96100.

Azelmat, K., Sayah, F., Mouhib, M., Ghailani, N. and El-Garrouj, D. (2005) Effect of gamma irradiation on fourthinstar Plodia interpunctella (Hubner) (Lepidoptera: Pyralidae). J. Stored Prod. Res., 41: 423-431.

Bakr, E.I., EI-Kosary, S., El-Bana, A. and Ghazawy, H. S. (2007) Effect of naa on fruit setting, bunch weight and fruit characteristics of samani and zaghloul date palm cultivars. Thinning \& Growth Reg., 361-380

Brenner, M. L and Cheikh N. (1995) The role of hormones in photosynthate partitioning and seed filling, In: Davis PJ (ed) Plant hormones: physiology, biochemistry, and molecular biology, 2nd edn. Kluwer Academic Publishers, Dordrecht, The Netherlands: 649-670.

Davis, P. J. (2004) The plant hormones: their nature, occurrence and functions. In: Plant Hormones, Davis, P.J. (Ed.), Kluwer Academic Publishers, Dordrecht, The Netherlands: 1-15.

Dokoozlain, N. K., (2000), Plant growth regulator use for table grape production in California. Proc. $4^{\text {th }}$ Int. Sympo. Tabel Grape., Inia. Cl.: 129-143.

El-Dengawy, E. F. A., Samaan, L. G. ,. ElShobaky, M. A; El-Kadi, S. M.and M Saleh, - A. A. (2018) Evaluation of 
Rutability, Quality and Microbial Load in Hayani date palm fruits during cold Storage as affected by applying some safe postharvest treatments, J. Plant Production, Mansoura Univ., Vol. 9 (10): 805-813.

El-Kosary, O. (2009) Effect of GA3, NAA and cytophex spraying on Samany and Zaghloul date palm yield, fruit retained and characteristics, J. Hort. Sci Ornamen. Plants, 1, 49-59.

El-Rayes, D. A. (2009) Effect of carbon dioxide-enriched atmosphere during cold storage on limiting antioxidant losses and maintaining quality of 'Barhy' date fruits. JKAU: Met., Env. and Arid Land Agric. Sci., 20 (1): 3-22.

FAO (2021) Food and Agriculture Organization of the United Nation. The statistics of food and agriculture organization of the United Nations. http://www.fao.org.

Faissal, F. A.; Mohamed, K. K. and Hamdy, I. M. I. (2014) The synergistic effects of using plant extracts and salicylic acid on yield and fruit quality of Keitte mango trees, Stem Cell, 5(2): 30-39.

Friedman, M. (2007) Overview of antibacterial, antitoxin, antiviral, and antifungal activities of tea flavonoids and teas. Mol. Nutr. Food Res., 51: 116-134.

Gameel, A. F. A. (2012) Reducing Chilling Injury of Eureka Lemon Fruits During Cold Storage. Ph.D. Thesis in Pomology, Fac. Agric., Tanta Univ., Egypt, pp 219.

Hussein, M. A., Mahmoud H. M., Amen K. I. A. and Mustafa M. (1996) Changes in the physical and chemical characteristics of Zaghloul dates during development and maturity as affected by GA3 and CCC under Assiut Governorate conditions. Proceedings of the Third Symposium on the Date Palm in Saudi Arabia. January, 17-20:389-404.

Janisiewicz, W. J. and Korsten, L. (2002) Biological control of postharvest diseases of fruits, Ann. Rev. Phytopathology, 40, 411444.

Kassem, H. A., Al-Obeed, R. S. and Ahmed, M. A. (2010) Extending harvest season, improving fruit quality and shelf life of 'Barhee' date palm by preharvest sprays. Acta Hort., 882:147-154

Kassem, H. A., Al-Obeed, R. S. and Ahmed, M. A., (2011), Extending harvest season and shelf life and improving quality characters of Barhee dates Adv. Agric. \& Botanics-Int. J. Bioflux Soc., 3(1): 67-75.
Kassem, H. A., Al-Obeed, R. S. and Ahmed, M. A. (2012) Effect of bioregulators preharvest application on date palm fruit productivity, ripening and quality. Afri. $J$. Agric. Res., 7(49): 6565-6572.

Khalil, H. A. (2015) Improving yield, fruit quality and storability of 'Zaghloul' date palm cultivar by pre-harvest sprays of some growth regulators and bunch bagging, Egypt. J. Hort. Vol. 42, No. 2, pp. 825-838.

Kuiper, D. (1993) Sink strength: established and regulated by plant growth regulators. Plant Cell Environ. 16:1025-1026.

Lester, G. E. and Grusak, M. A. (2004) Field application of chelated calcium: postharvest effects on cantaloupe and honeydew fruit quality. Hort. Techno., 14, 29-38.

Mahajan, B. V. C. and Dhatt, A. S. (2004) Studies on postharvest calcium chloride application on storage behaviour and quality of Asian pear during cold storage. Int. J. Food Agric. Environ., 2 (3-4), $157-$ 159.

Mair, V. P. and Metzler, D. M. (1962) Enzymatic Action Soften Dates, Agri. Res. Wash., 11(3):15.

Malik, C. P., Singh, M. B. (1980) Plant enzymology and histoenzymology, A text manual, kalyani Publishing, New Delhi, India.

Marzouk, H. A. and Kassem, H. A. (2011) Improving yield, quality, and shelf life of Thompson seedless grapevine by preharvest foliar applications. Sci. Hort., 130, 425-430.

Melouk, A. M. (2007) Effect of phenylalanine, putrescine and spermidine on yield and berry quality Thompson seedless grapevines. J. Agric. Sci...Mansowra Univ. 32(2):1245-1254.

Merwad, M. A., Eisa, R. A. and Mostafa, E. A. M. (2015) Effect of some Growth regulators and Antioxidants sprays on productivity and some fruit quality of Zaghloul date palm. International Journal of Chem Tech Research 8 (4): 1430- 1437.

Mohammed, S. and Shabana, H. R. (1980) Effects of naphthaleneacetic acid on fruit size, quality, and ripening of Zahdi date palm, Hort, Science, 15, 724-725.

Mohammed, S. A., Awad, M. A. and AlQurashi, A. D. (2014) Antioxidant activity, antioxidant compounds, antioxidant and hydrolytic enzymes activities of „Barhee" dates at harvest and during storage as affected by pre-harvest spray of some growth regulators, Sci. Hortic., 167, 91- 99. 
Moran R., Porath, D. (1980) Carotenoids determination in intact tissues Plant Physiol. 65:47-54.

Mostafa, R. A. A. (2015) Effects of zinc, Boron and active dry yeast sprays on yield and fruit quality of Zaghloul date palm. Arab Univ. J. Agric. Sci., Ain shams Unive., Cairo, 23 (2): 467- 473.

Moustafa, A. A., Seif, S. A. and Abou-ElAzayem, A. I.. (1996) Date fruit response to naphthalene acetic acid, Proceedings of the third symposium on the date palm in Saudi Arabia. January, 17-20.: 369-378.

Moustafa, A. A. and Seif, S. A. (1996), Effect of ethrel and GA treatments on yield and fruit quality of seewy date palms, grown in El-Fayoum Governorate. Proceedings of the Third Symposium on the Date Palm in Saudi Arabia. January, 17-20: 379-388.

Omaima, M. Hafez; Malaka, A. Saleh and Naguib, M. M. (2012) Quality improvement and storability of some date palm cultivars by safe postharvest treatments, Australian J. of Basic and Applied Sci., 6(3): 542-550.

Rizk-Alla, M. S. and Meshrake, A. M. (2006) Effect of pre-harvest foliar application of GA3 and some safe treatments on fruit quality of Crimson seedless grapevines and its effect on storage ability, Egypt. J. Appl. Sci. 21 (6): 210-238.

SAS Institute (2000) Usrer Guide : Statistic version 8.02 SAS Institute, Cary, NC, USA.

Sabry, G. H.; El-Helw, H. A. and Abd ElRahman, A.S. (2011) A study on using jasmine oil as a breaking bud dormancy for flame seedless grapevines, Report and Opinion, 3(2): 48-56.

Shen, C. L., Cao, J. J., Dagda, R. Y., Tenner, J., Chyu, T. E. and Yeh, J. K. (2011) Supplementation with green tea polyphenols improves bone microstructure and quality in aged, orchidectomized rats. Calcified Tissue Internacion- al, 88, 455-463. http://dx.doi.org/10.1007/s00223-011-94771.

Shimim, F., Ali, M. A., Ashgar, M., Din, A. Babu, I.and Yasmin, Z. (2013) Controlled ripening of date palm fruit and impact on quality duration postharvest storage, Ext $J$ App Sci., 1 (2): 53-57.

Sinha, M. M., Tripathi, S. D., Tiwari, J. P. and Mishra, R. S. (1983) Effect of Alar and CCC on flowering and fruiting in peach cv. Alexandria. Punjab Hort. J., 23: 43-46.

Stern, R. A., Ben, R., Arie, A. S. and Flaishman, M., (2006), Cytokinins increase fruit size of Delicious and Golden Delicious (Malus domestica) apple in warm climate. J. Hort. Sci. Biotech. 18:5156.

Thompson, K.A. and Abboodi, A.H. (2003) Modified Atmosphere Packaging, Proceedings of the International Conference on Date Palm. King Saud Univ., Qassim, Kingdom of Saudi Arabia, 363-394.

Vicente, A. R.; Martínez; G. A., Chaves, A. R. and Civello, P. M.,(2003) Influence of selfproduced $\mathrm{CO}_{2}$ on postharvest life of heattreated strawberries, Postharvest Biol. Technol. 27: 265-275.

Yehia, I. and Zaki, Zeinab A, (2020), Effect of a mechanical pollination on quality of "Zaghloul" date-palm fruits during cold storage, J. Hort. Sci. \& Ornamen. Plants, 12 (2): 97-109.

Yuan, J., Xiong, B. and Yu dong, Z. M. (2004) Advances of the application of CPPU to fruit trees, Northern Fruits. p. 02.

Zaghloul, A. E.; Abd El- Naiem, A. E. and Hamdy, E. E. (2011) Application of activated jasmine oil on navel orange trees bimproving storability and shelf-life, J. Agric. Res. Kafer El-Sheikh Univ., 37(2): 370-384.

Zai-xin, C. and Yong-ling, L., (2005), Effects of spraying CPPU on fruit growth and quality of Etao-1, J. Yangtze University (Natural Science Edition) Agric. Sci. p. 04.

Zaki, Zeinab A, Yousef, A. R., Abd ElMoneim, E. A. and Emam, H. E., (2017), Effect of some Natural Extracts on Maintaining Quality of Zaghloul Date Palm Fruits during Cold Storage, Middle East J. Agric. Res., 6(2): 464-473. 


\section{تحسين المحصول والجودة والقدرة التخزينية لثمار النخيل السمانى بأستخدام بعض معاملات ما قبل وما بعد الحصاد}

ـ ثناء مصطفى درويش عز (1)، محمود احمد محمد على(1)، إقبال زكريا على أحمد(2)، محمد حسن عبد الحميد خلف(3)،

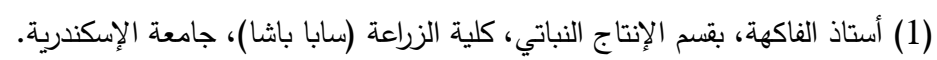
(2) أستاذ الفاكهة، معهد بحوث البساتين، مركز البحوث الزبراعية، الجيزة.

(3) باحث مساعد، معهد بحوث البساتين، مركز البحوث الزراعية، الجيزة.

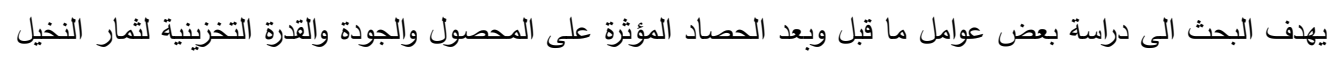

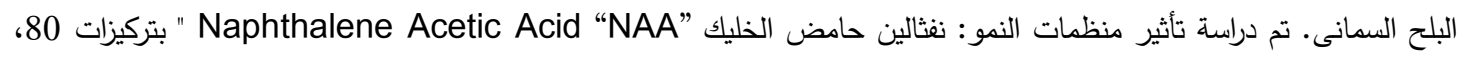
90 ميلليجرام/تتر فى مرحلة الحبابك (hababak stage)، 50، 60 ميلليجرام/تتر فى مرحلة كسر لون الثمار ( beginning of

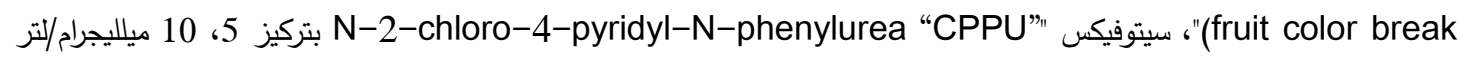
فى مرحلة الحبابك (hababak stage)، 10، 15 ميلليجرام/لتر فى مرحلة تغير لون الثمار ،" على كمية المحصول والخواص الطبيعية

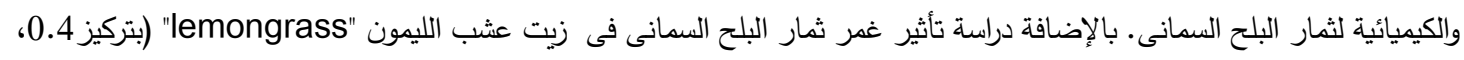

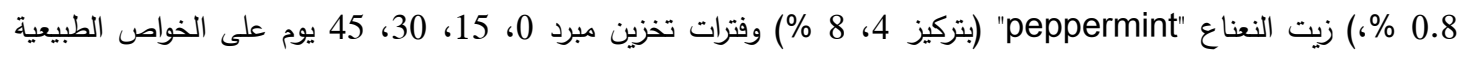

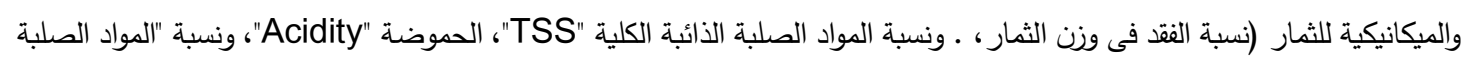

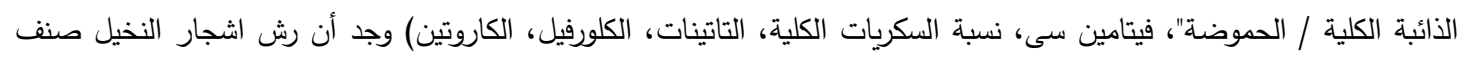

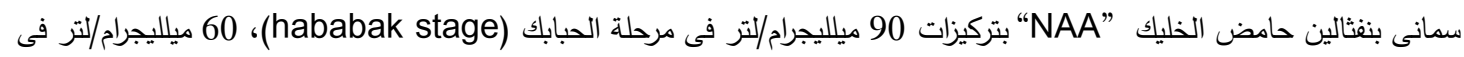

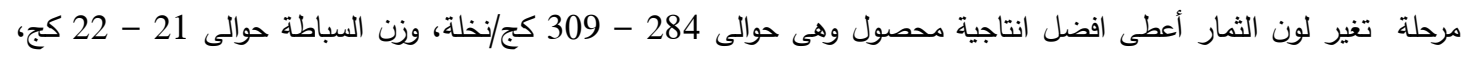

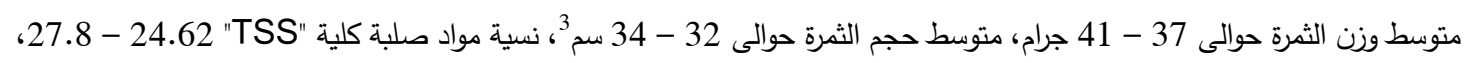

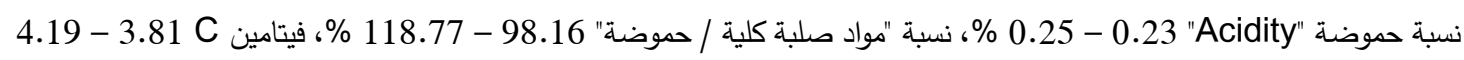

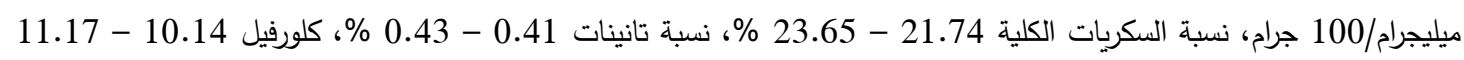
ميليجرام/100جرام، الكاروتين 4.08 - 4.45 ميليجرام/100 جرام، كمام كما وجد أن الثمار الناتجة من رش النخيل بنفالين حامض الخليك

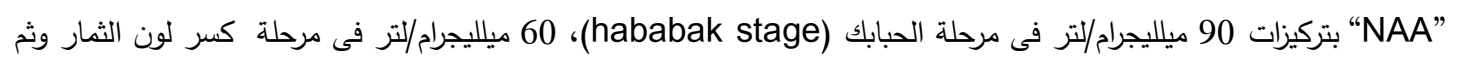

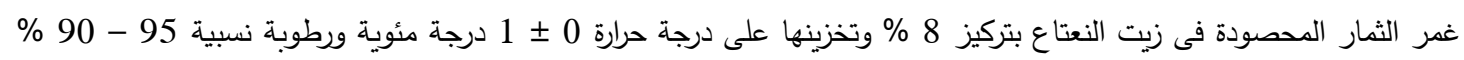

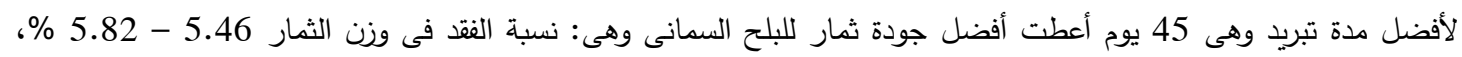

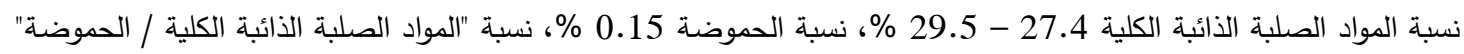

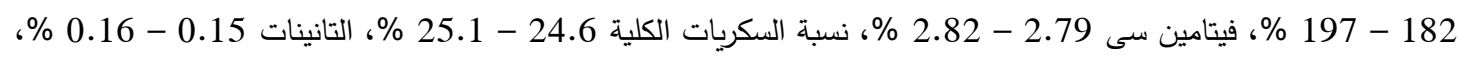
الكلورفيل 5.1 - 6.7 ميليجرام/100 جرامين، الكاروتين 5.7 - 6.2 ميليجرام/100 جرام لكلا من موسمي التجارب (2019، 